\title{
BLOOD UREA DETERMINATIONS IN 211 CASES *
}

\author{
HAROLD SCHWARTZ, M.D., AND CAROLINE MCGILL, M.D. \\ BUTTE, MONT.
}

\section{LITERATURE REVIEW}

Increased urea in the blood was first demonstrated in 1823 by Prevost and Dumas, ${ }^{1}$ while working with nephrectomized animals. Bostock, ${ }^{2}$ in 1829 , noticed an increase in the blood urea of certain aibuminurics. Richard Bright ${ }^{3}$ with his co-workers-Prout, Babbington, and Christison (1836)-confirmed this observation and recog. nized it to be of clinical importance in nephritis. Babbington and Christison also made estimations of urea in body fluids.

Following the qualitative demonstration of blood urea, quantitative determinations were attempted by both French and German clinicians. Picard ${ }^{4}$ (1856) was the first to determine that the amount of blood urea varies with the nitrogen intake.

Interest in the subject abated about this time, and for a period of forty years the references in the literature were infrequent. Schöndorff ${ }^{5}$ (1899) revived the subject by an examination of the previous work, adding to it his own more accurate results, which confirmed the work of his predecessors. He observed that the urea fraction of the total nonprotein nitrogen of the blood was variable. Ascoli, ${ }^{6}$ in 1901, using a precipitation method (acetic acid and sodium chlorid), and Strauss ${ }^{7}$ (1902) with a similar method (heat and acetic acid), found that in cases of severe nephritis there was usually nitrogen accumulation. He found a marked increase in the terminal state. Müller ${ }^{8}$ (1905) recognized urea retention to be of the highest value in diagnosing cases of uremia.

F. Widal and Javal ${ }^{9}$ (1905) found that urea was retained in some cases of Bright's disease, and advocated a diminished protein diet in those cases.

* Submitted for publication July 21, 1915.

1. Prevost and Dumas: Ann. de chimie et de physique, 1823, xxiii, 90.

2. Bostock: Edinburg Med. and Surg. Jour., 1829, xxxii, 28.

3. Bright, Babbington, and Christison: Guy's Hosp. Rep., 1836, i, 360.

4. Picard: Thèse de Strassburg, 1856.

5. Schöndorff : Arch. f. d. ges. Physiol. (Pflüger's), 1899, 1xxiv, 358.

6. Ascoli: Pfluger's Arch. f. path. Anat., 1901, 1xxvii, 103.

7. Strauss: Die Chronische Niereutzündungen in ihrer Einwirkung auf die Blutflüssigkeit und deren Behandlung, Hirschwald, Berlin, 1902.

8. Müller: Verhandl. der deutsch. path. Gesellsch., 1904-5, vii-ix, Supplement 80 .

9. Widal and Javal: Semaine méd., 1905, xxv, 313. 
Von Noorden ${ }^{10}$ (1907) obtained inconstant findings, but believed that the nitrogen accumulation in the blood constituted one of the nost important phenomena of renal insufficiency.

Obermayer and Popper ${ }^{11}$ (1909) confirmed the results of previous workers, finding the incoagulable nitrogen higher in uremic cases than in normal cases, and emphasized especially the increase in the urea fraction. They used heat and acetic acid for coagulation of blood proteins.

Hohlweg ${ }^{12}$ (1911) used acetic acid and monopotassium phosphate, half saturated with sodium chlorid, to precipitate the blood proteins. He found increased values in uremia, but found them also in other conditions. While he considered nitrogen accumulation in the blood nonspecific of uremia, he thought it was of some prognostic value.

Widal $^{13}$ (1911) using the hypobromite method, based a prognosis on the amount of urea per liter; patients with 1 to $2 \mathrm{gm}$. per liter rarely live more than a year; with 2 to $3 \mathrm{gm}$. only months or weeks; and with more than $3 \mathrm{gm}$. a very short time. This prognosis, however, he did not apply to cases with renal obstruction, where such obstruction could be removed, as here he found the urea dropped when the obstruction was relieved. He found the retention was more permanent in chronic Bright's disease. He believed the amount of biood urea was of definite value in the prognosis, especially of those cases difficult to determine from the clinical symptoms alone.

Foster $^{14}$ (1912) using an alcohol precipitation and fractional separation method, found a considerable increase in nonprotein nitrogen in severe nephritis and in some other conditions. When the total nitrogen reached $1 \mathrm{gm}$. per liter, he regarded the prognosis as grave.

Rowntree and Fitz ${ }^{15}$ (1913) used the original Widal method in part of their determinations, but in the main they precipitated by the Widal method and then determined the nitrogen by the Kjeldahl method. They reported the results obtained in fifty-seven cases. No increase of blood urea was found in suspected nephritis (i. e., clinically). In mild nephritis the average was $0.38 \mathrm{gm}$. urea per liter; in cases of advanced nephritis $0.783 \mathrm{gm}$. per liter; cases of cardiac decompensation without nephritis $0.70 \mathrm{gm}$. per liter; and cardiac decompensation associated with nephritis $0.831 \mathrm{gm}$. per liter. In summarizing, they believed that the accumulation of nonprotein nitrogen in the blood of nephritics was of considerable prognostic value. When

10. Von Noorden: Metabolism and Practical Medicine, 1907, ii, 486.

11. Obermayer and Popper: Ztschr. f. klin. Med., 1911, 1xxii, 332.

12. Hohlweg: Deutsch. Arch. f. klin. Med., 1912, civ, 216.

13. Widal: Bull. et. mém. Soc. méd. d. hôp. de Paris, 1911, xxxii, 627.

14. Foster: The Archives Int. Med., 1912, x, 414.

15. Rowntree and Fitz: The Archives Int. Med., 1913, xi, 258. 
it occurred it was confirmatory evidence of renal insufficiency, whereas the absence of such increase was of less importance. As a point in differentiating cardiac and renal diseases they believed it was also of importance.

Frothingham, Fitz, Folin and Denis ${ }^{16}$ (1913) found that the blood urea and the phenolsulphonephthalein excretion varied from normal in animals subjected to experimental uranium nephritis, and the amount of such variation agreed with the amount of kidney destruction. They observed a gradual increase in urea as nephritis developed and a gradual decrease as the kidney recovered. They concluded that the urea in the blood is a measure of the difference between the waste nitrogen urea produced in metabolism and the amount excreted in the urine. Such a retention of nitrogen in experimental nephritis was found also by Siegel, ${ }^{17}$ Pearce, Hill and Eisenbrey, ${ }^{18}$ Austin and Eisenbrey, ${ }^{19}$ Folin, Karsner, Howard and Denis ${ }^{20}$ and Mosentha1 ${ }^{21}$ (uranium, cantharidin, chromate, etc., nephritis). Mosenthal stated that there "Seems no doubt that kidney insufficiency in these cases is responsible for the retention." Karsner ${ }^{22}$ also found retention in experimental arsenical nephritis, especially during the stage in which tubular destruction was most marked.

Soper and Granat ${ }^{23}$ (1914) studied a series of ninety-seven cases, observing the urea content in spinal fluids. Their work will be referred to later under discussion of body fluids.

- Folin, Denis and Seymour ${ }^{24}$ (1914) reported a series of clinical experiments showing the relation of the nonprotein nitrogen and of the urea of the blood of nephritics to the amount of protein intake. Under low protein diet they were able to reduce the urea content from $0.67 \mathrm{gm}$. per liter to practically a normal amount. They conclude that the rational means of determining protein tolerance is by dietermining the nonprotein nitrogen retention and not by blood pressure findings. They found no connection between nitrogen retention and blood pressure as had previously been described by Strauss, who believed that the high blood pressure of nephritics is frequently associated with nitrogen retention.

16. Frothingham, Fitz, Folin, and Denis: The Archives Int. Med., 1913, xii, 245.

17. Siegel: Ztschr. f. exper. Path. u. Therap., 1907, iv, 561.

18. Pearce, Hill, and Eisenbrey: Jour. Exper. Med., 1910, xii, 196.

19. Austin and Eisenbrey: Jour. Exper. Med., 1911, xiv, 366.

20. Folin, Karsner, Howard, and Denis: Jour, Exper. Med., 1912, xvi, 789.

21. Mosenthal: The Archives Int. Med., 1914, xiv, 844.

22. Karsner and Denis: Jour. Exper. Med., 1914, xix, 63.

23. Soper and Granat: The Archives Int. Med., 1914, xiii, 131.

24. Folin, Denis, and Seymour: The Archives Int. Mfd., 1914, xiii, 224. 
Agnew $^{25}$ (1914), using the method of Folin and Denis, ${ }^{25}$ found in the majority of cases of nephritis, when the excretion of phenolsulphonephthalein was below 40 per cent., there was an increase in the nonprotein blood nitrogen and in the blood urea. This did not hold true in cases of cardiac decompensation. He found the incoagulable nitrogen determinations valuable in the diagnosis of incipient uremia, coma, and in conjunction with phenolsulphonephthalein in cardiorenal diseases.

Frothingham and Smillie ${ }^{27}$ (1914), using the method of Folin and Denis, found many cases of chronic nephritis with normal nonprotein nitrogen in the blood. Cases showing $0.35 \mathrm{gm}$. per liter were clinically more severe than the cases with no retention, while the cases with 0.5 gm. or over were clinically of still more severe type. No nonnephritic cases showed nitrogen retention. They found that the excretion of phenolsulphonephthalein varied inversely with the retention of nitrogen, except in cases of cardiac decompensation. Blood pressure and pulse pressure they believed to be of less prognostic value than nitrogen retention.

Tileston and Comfort ${ }^{28}$ (1914), following the technic of Folin and Denis, observed a large series of cases (142). Their most important deduction was that in chronic nephritis without uremia the urea values were normal or moderately elevated. Cases of uremia showed great increase without exception. The excretion of phenolsulphonephthalein was proportional to the nitrogen retention. Outside of uremia, extremely large urea values, over $1 \mathrm{gm}$. per liter, were encountered only in severe anemias and intestinal obstruction. They found retention in chronic plumbism, lobar pneumonia, syphilis (36 per cent. of cases), diabetes with coma, and acute yellow atrophy of the liver. Normal values were obtained in eclampsia, chronic passive congestion, compensated valvular lesions, pericarditis, endocarditis, acute rheumatism, uncomplicated scarlatina, cerebral hemorrhage, functional nerve diseases, diabetes without coma, myxedema, exophthalmic goiter, and malignant disease. They believed the estimation of nitrogen to be of the greatest value in the diagnosis of uremia and also in the prognosis of chronic nephritis. They thought that the total nitrogen was of more prognostic importance than the urea nitrogen.

Ovsiannikova $^{29}$ (1914) found a mortality of 18 per cent. in cases of chronic nephritis with blood urea below $0.5 \mathrm{gm}$. per liter; 18 per

25. Agnew: The Archives Inr. Med., 1914, xiii, 485.

26. Folin and Denis: Jour. Biol. Chem., 1913, xiv, 29.

27. Frothingham and Smillie: The Archives Int. Med., 1914, xiv, 541.

28. Tileston and Comfort: The Archives Int. Med., 1914, xiv, 620.

29. Ovsiannikova: Russk. Vrach., 1914, xiii, 253. 
cent. for 0.5 to $1 \mathrm{gm}$. per liter; 58 per cent. for 1 to $2 \mathrm{gm}$. per liter; and 85 per cent. for 2 to $5 \mathrm{gm}$. per liter.

Widal, Weill and Radot $^{30}$ (1914) found that the phenolsulphonephthalein test and the urea in the blood serum ran parallel. They rose and fell together in normal cases and in cases of Bright's disease. The mere estimation of the urea content of the blood from time to time they believed to be a reliable and accurate index of the azotemia. In chronic kidney disease when the urea was less than $0.5 \mathrm{gm}$. per liter there was no question of azotemia; when $1 \mathrm{gm}$., they believed the test should be frequently repeated; when $2 \mathrm{gm}$., the prognosis was bad.

TABLE 1.-NORMAL

\begin{tabular}{|c|c|c|c|c|c|}
\hline \multirow[b]{2}{*}{ Number } & \multirow[b]{2}{*}{ Age } & \multirow{2}{*}{$\begin{array}{c}\text { Blood } \\
\text { Pressure }\end{array}$} & \multirow{2}{*}{$\begin{array}{l}\text { Phthalein, } \\
\text { Per Cent. }\end{array}$} & \multicolumn{2}{|c|}{ Blood Urea } \\
\hline & & & & $\begin{array}{l}\text { Two Hours } \\
\text { After Meals }\end{array}$ & $\begin{array}{c}\text { Seventeen Hours } \\
\text { Fasting }\end{array}$ \\
\hline 38 & 23 & 100 & 72 & 0.168 & $\ldots$. \\
\hline 39 & 21 & 102 & 87 & 0.168 & 0.120 \\
\hline 40 & 21 & 122 & 67 & 0.156 & 0.156 \\
\hline 41 & 21 & 122 & 82 & 0.120 & $\ldots .$. \\
\hline 43 & 20 & $\ldots$ & .. & 0.180 & $\ldots$. \\
\hline 47 & 24 & 116 & .. & 0.192 & $\ldots .$. \\
\hline 58 & 22 & 100 & 67 & 0.192 & $\ldots .$. \\
\hline 11 & 36 & 112 & 79 & 0.180 & 0.132 \\
\hline 69 & 21 & 110 & .. & $\ldots .$. & 0.108 \\
\hline 77 & 23 & $\ldots$ & 65 & 0.160 & $\ldots .$. \\
\hline 82 & 21 & $\ldots$ & 42 & 0.220 & $\ldots .$. \\
\hline 83 & 28 & 126 & 60 & 0.216 & $\ldots .$. \\
\hline 176 & 25 & 122 & 82 & 0.262 & $\ldots$. \\
\hline 195 & 20 & 120 & 50 & 0.204 & ..... \\
\hline 196 & 26 & 132 & 65 & 0.108 & ..... \\
\hline 197 & 22 & 120 & 70 & 0.120 & $\ldots .$. \\
\hline
\end{tabular}

Farr and Krumbhaar ${ }^{31}$ (1914) stated that in cirrhosis of the liver the total nitrogen was increased only in cases accompanied by definite nephritis. They did not support the view held by Morel and Mouriquand, ${ }^{32}$ and by some other investigators, that in destructive diseases of the liver the percentage of urea to the total nitrogen was decreased; to the contrary, they found that the percentage of urea remained normal.

30. Widal, Weill, and Radot: Presse. méd., 1914, xxii, 565.

31. Farr and Krumbhaar: Jour. Am. Med. Assn., 1914, 1xiii, 2214.

32. Morel and Mouriquand: Bull. et. mém. Soc. méd. d. hôp. de Paris, 1913, $\mathrm{xxxv}, 266$. 
Mosenthal $^{21}$ (1915), in a series of interesting experiments, was able to produce in dogs experimental uranium nephritis of two types. In nephritis of moderate severity there was an increase in nitrogen elimination. This increase he demonstrated experimentally to be due, not to any previous retention, but to an increased protein catabolism. The more severe cases showed a decreased elimination of nitrogen in the urine with a true nitrogen retention due to kidney insufficiency. He also showed that a gain or loss of water in the body was a factor that influenced the quantitative estimations of nonprotein nitrogen in the blood.

Foster $^{33}$ (1915) observed a series of cases of severe cardiac decompensation without nephritis, and found in them an increase in the nonprotein nitrogen averaging $0.6 \mathrm{gm}$. per liter. In four of these cases necropsy substantiated the clinical findings. The nonprotein nitrogen in chronic parenchymatous he found lower than in chronic interstitial nephritis. In general, he found the most pronounced nitrogen increase in cases with high arterial pressure. He states that uremia may occur when the nitrogen is low, that is, no higher than in a latent nephritis. The convulsive type of uremia showed a nitrogen content double that of the asthenic type. A high nonprotein nitroger in the absence of uremic symptoms he believed to be of more definite prognostic value than in the presence of uremic symptoms, while a normal finding did not exclude a remotely fatal issue.

Rowntree, Marshall, and Baetjer ${ }^{34}$ (1915) also reported two cases of myocardial insufficiency with necropsies showing no kidney changes except chronic passive congestion. Clinically, both showed urea retention, 0.67 and $1.1 \mathrm{gm}$. per liter, respectively.

\section{TECHNIC}

We have used in this series of experiments the urease method of Marshall, ${ }^{35}$ fully described by the author.

\section{BLOOD UREA IN NORMAL CASES}

The several observers have obtained widely varying values for the normal blood urea, largely due to the method employed. A glance at Table 2 will show this clearly.

Our observations cover a series of sixteen cases, all persons in apparently perfect physical condition. The urine in each case was normal. The average amount of blood urea obtained after seventeen hours fasting was $0.129 \mathrm{gm}$. per liter. Two and one-half hours after

33. Foster: The Archives Int. Med., 1915, xv, 356.

34. Rowntree, Marshall, and Baetjer: The Archives Inr. Med., 1915, xv, 543.

35. Marshall: Jour. Biol. Chem., 1913, xiv, 283; ibid., 1913, xv, 487. 


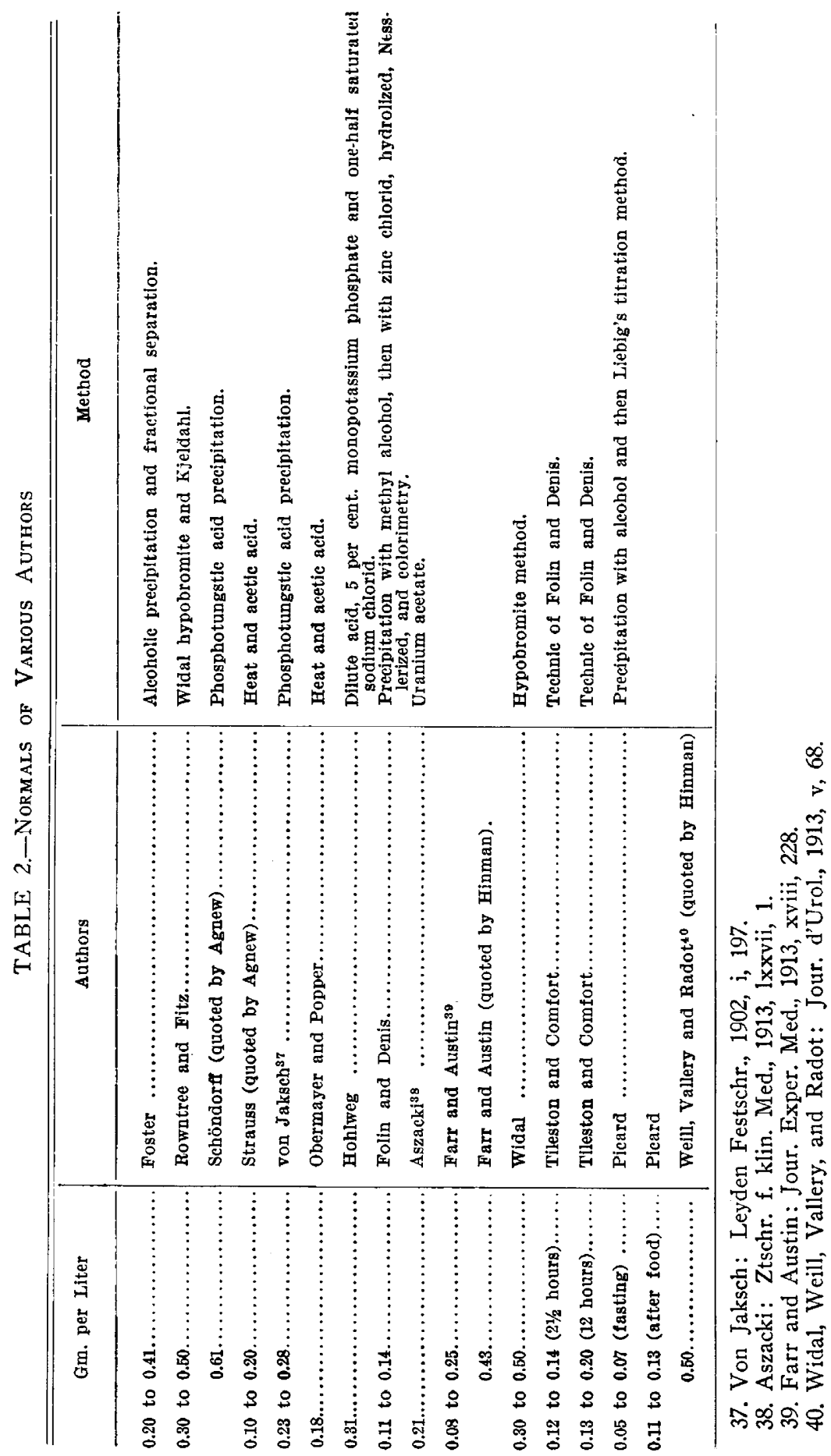


a heavy protein meal this was increased to $0.175 \mathrm{gm}$. per liter, or an average increase of $0.046 \mathrm{gm}$. per liter. Reference to Table 1 will show that the values obtained varied from $0.108 \mathrm{gm}$. per liter to $0.252 \mathrm{gm}$. per liter, in no case reaching $0.300 \mathrm{gm}$. per liter. The average per cent. of phenolsulphonephthalein excreted in two hours was 68 .

\section{RELATION OF PROTEIN INTAKE}

That the amount of protein ingested had a distinct bearing on the quantity of blood urea, was observed by Picard in 1856 . He found also that the time for taking blood for examination, with reference to food intake, caused certain variations. These observations have been repeatedly confirmed and emphasized by different authors.

Case 80, of our own observation, demonstrates this very clearly. A normal individual, with a phenolsulphonephthalein excretion of 60 per cent., had a blood urea of $0.326 \mathrm{gm}$. per liter. She gives a history of being a heavy meat eater. On a low protein diet for a period of three days the blood urea dropped to $0.168 \mathrm{gm}$. per liter; later, on a moderate protein diet the value increased to $0.240 \mathrm{gm}$. per liter. In nephritics, who have been given a low protein diet, we have also observed a drop in the blood urea (Case 56). The practical value of giving a low protein diet to decrease the nonprotein nitrogen in the blood of nephritics, has been recently demonstrated by various authors (Folin, Denis and Seymour, Tileston and Comfort, etc.).

\section{CAUSES OF BLOOD UREA INCREASE}

The finding of a normal as well as an increased amount of urea in nephritics, along with the fact that there is increased urea in numerous pathological conditions, in which no clinical or pathological cvidence of nephritis exists, leads us to the conclusion that blood urea increase cannot be explained by renal insufficiency alone. Faulty kidney excretion, resulting in true nitrogen retention, is no doubt the chief factor in cases of nephritis, but many other cases cannot be explained on the basis of retention. We observe in some cases involving general metabolism, without any evidence of nephritis, an increased blood urea. Cases of exophthalmic goiter show a moderate increase. In one case we observed still greater increase during a condition of hyperthyroidism following a partial gland resection. This increase dropped to normal simultaneously with the improvement of the patient.

Whether increased protein catabolism alone explains these cases is aifficult to state. There may be an abnormal urea combination in the blood, which makes elimination by the kidney impossible, as has been suggested by Mosenthal. 


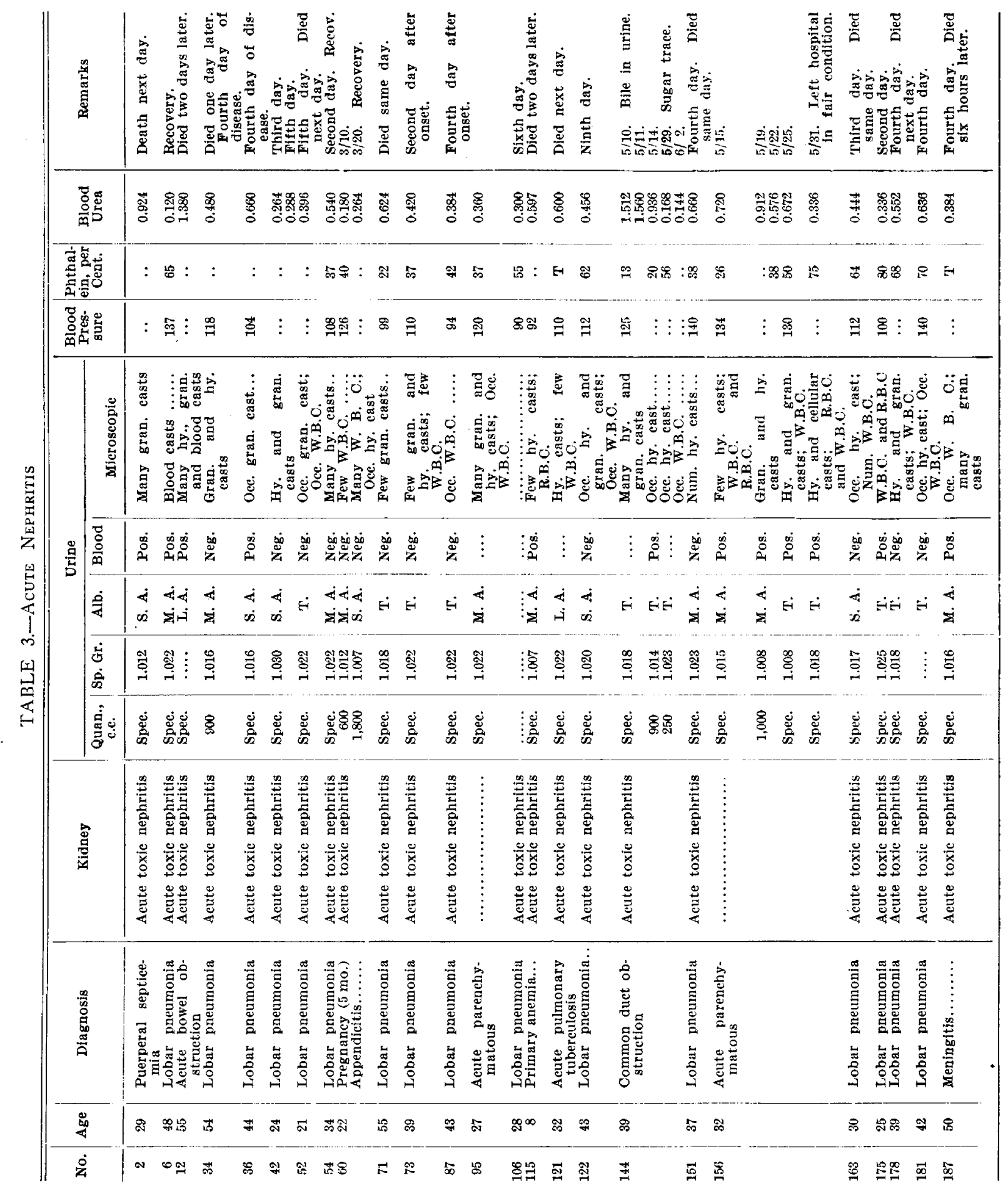


Cases of acute infection often present the same picture. Here there is undoubtedly increased catabolism along with the elevation of temperature. It seems quite probable that an abnormal urea compound, as well as an absolute increase in the amount of urea nitrogen formed, combined with kidney insufficiency of varying degree, occurs in the terminal state.

That pure circulatory disturbance may give rise to increase in blood urea has been demonstrated in cases of cardiac decompensation, where necropsy showed the absence of kidney lesions (Foster).

Another factor which has to be considered is the percentage of water in the body fluids. In cases of persistent vomiting, esophageal stenosis, acute hemorrhage, etc., we have observed an increase in the blood urea, and conversely, in a case of high blood urea, we have observed a distinct drop following the addition of a considerable quantity of water to the body fluids. Concentration of and dilution of the blood probably account in part at least for these phenomena.

UREA IN PATHOLOGICAL CONDITIONS

In studying various pathological conditions we have considered a blood urea above $0.250 \mathrm{gm}$. per liter as abnormal. For purposes of classification we have divided the cases into clinical groups, including (1) acute nephritis, (2) suspected chronic nephritis, (3) mild chronic nephritis, (4) advanced chronic nephritis, (5) advanced chronic: nephritis with cardiac decompensation, (6) miscellaneous genitourinary, (7) diseases of heart, (8) anemias, (9) acute infections, (10) chronic infections, (11) diabetes mellitus, (12) diseases of thyroid, (13) malignancy, (14) miscellaneous cases.

\section{ACUTE NEPHRITIS}

Twenty-five cases of acute nephritis were observed. Of these eighteen were toxic nephritis accompanying lobar pneumonia. The urea averaged $0.578 \mathrm{gm}$. per liter, thus showing a definite increase. Only three cases showed a normal amount of urea. All showed albumin and casts in the urine. Twenty-two phthalein tests were made; sixteen showed decreased elimination.

Case 12 of intestinal obstruction following operation showed normal urea before operation. With developing obstruction, many hyaline and granular casts, with a large amount of albumin, appeared in the urine. The blood urea was $1.390 \mathrm{gm}$. two days before death.

Cases 95 and 156 were acute parenchymatous nephritis of no determined etiology. Case 156 entered the hospital the third day of illness, complaining of weakness and headache. His previous history was entirely negative. He showed a medium amount of albumin, casts, 


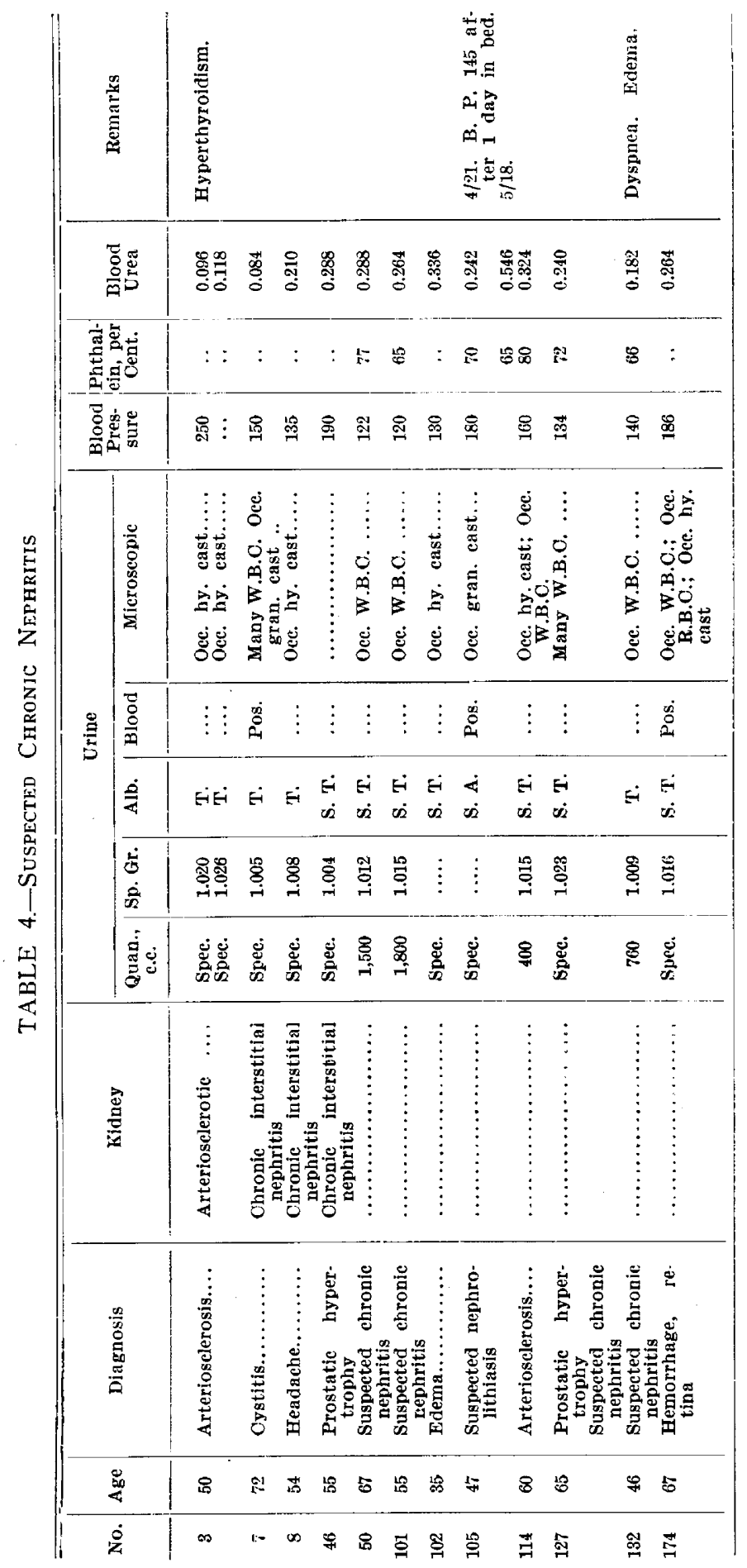


white and red blood cells, a phthalein of 26 per cent., and urea of $0.720 \mathrm{gm}$. per liter. A few days later the urea rose to $0.912 \mathrm{gm}$. per liter. With improvement in symptoms the urea fell promptly and phthalein elimination increased to normal.

Case 144 was common duct obstruction. When the patient entered the hospital she showed blood urea of $1.512 \mathrm{gm}$. per liter, with 1.3 per cent. phthalein excretion. The common duct opened spontaneously and at the same time the accompanying nephritis began to clear. The urea and phthalein promptly returned to normal.

These cases followed practically the same course observed by the various investigators of acute experimental nephritis.

\section{SUSPECTED CHRONIC NEPIIRITIS}

Twelve cases which were clinically suspected of being nephritis, showed an average urea of $0.248 \mathrm{gm}$. per liter, which is a normal value. The phthalein excretion was normal on all the cases which were examined. Reference to Table 4 will show the details of each case.

\section{MILD CIIRONIC NEPHRITIS}

Table 5 shows the results in the nineteen cases of mild chronic nephritis. Of these five were parenchymatous and fourteen were interstitial nephritis. The average blood urea was $0.288 \mathrm{gm}$. per liter. Five of the cases showed normal blood urea. The phthalein excretion in this group was, with one exception, normal.

\section{ADVANCED CHRONIC NEPHRITIS}

Sixteen cases of advanced chronic nephritis came under our observation. The average blood urea of these cases was $0.444 \mathrm{gm}$. per liter. Three cases showed normal values.

Two cases of albuminuric retinitis associated with chronic parenchymatous nephritis were observed. It is interesting to note that both of these cases showed a normal urea. Widal has stated that albuminuric retinitis is always associated with azotemia. Tileston and Comfort had one case which also showed a normal urea value, but in the cases of long standing eye symptoms the urea was increased. Both of the cases coming under our observation were of brief duration, as far as the retinitis was concerned. It is of interest to note that in one case with a urea of $0.180 \mathrm{gm}$. per liter the excretion of phthalein was but 15 per cent.

One case of uremia was observed. This was of transitory character, following a prostatectomy. The maximum urea at the time the patient had uremic symptoms was $1.008 \mathrm{gm}$. per liter, with but a trace of phthalein excreted. This case is also of interest, because 


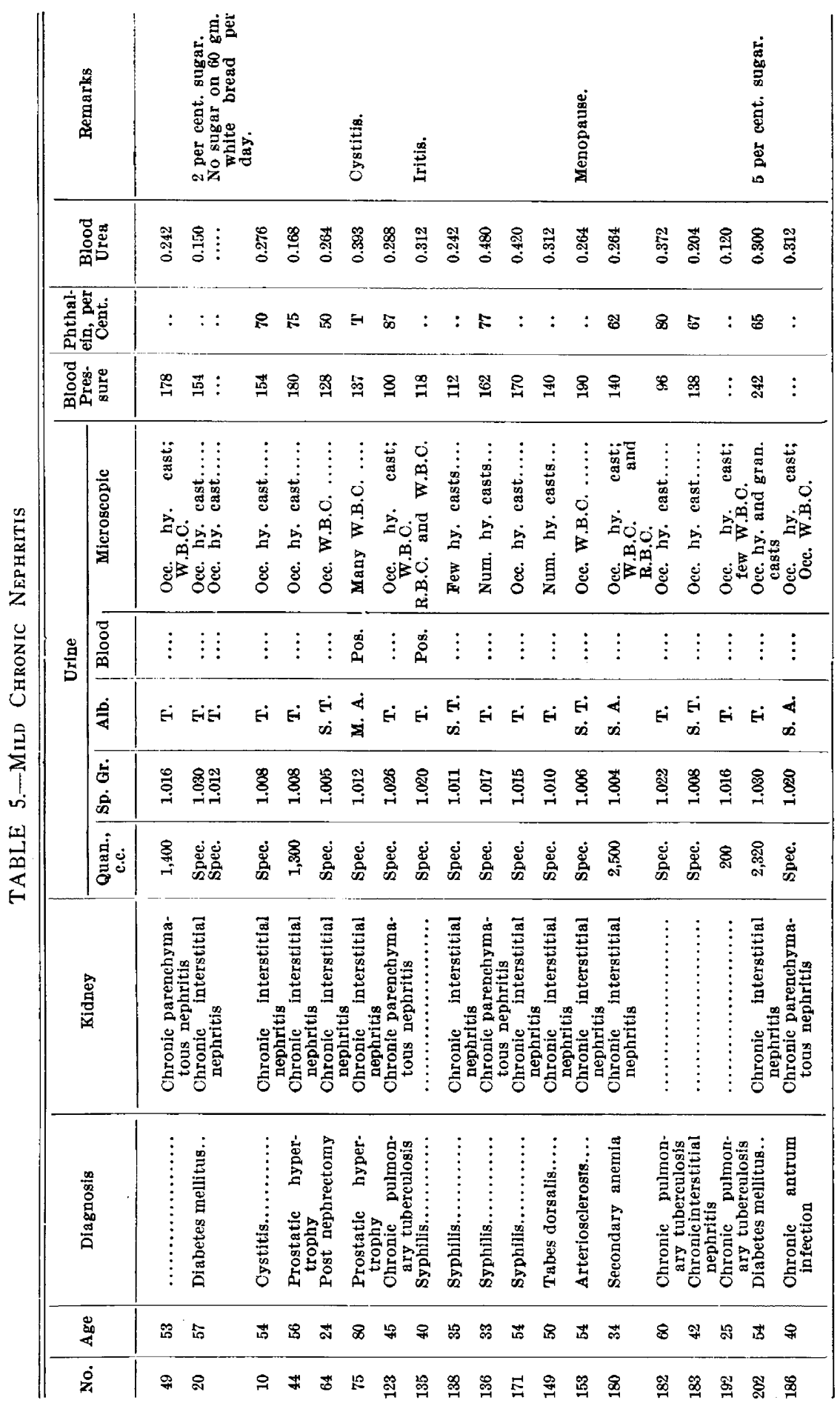




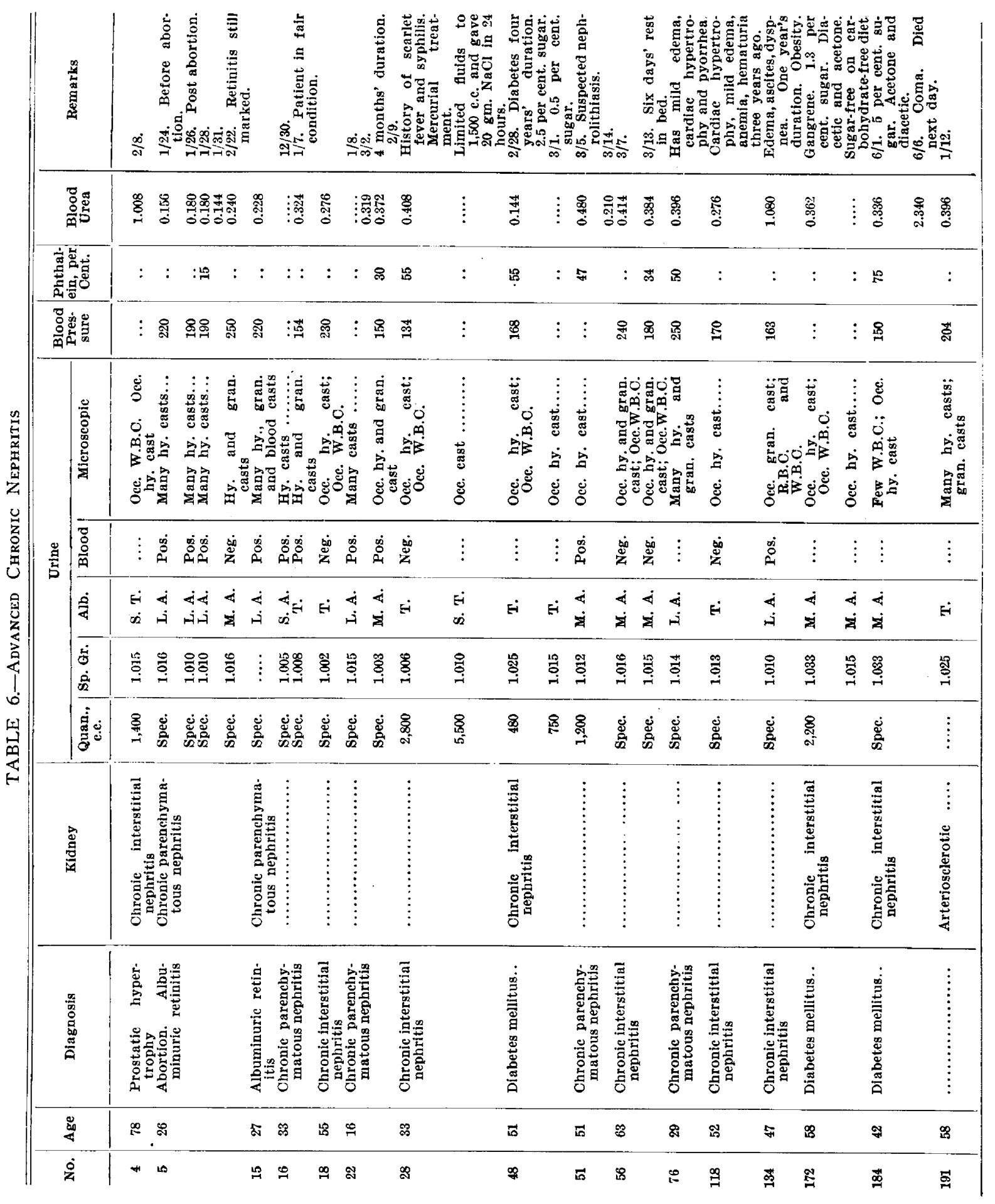




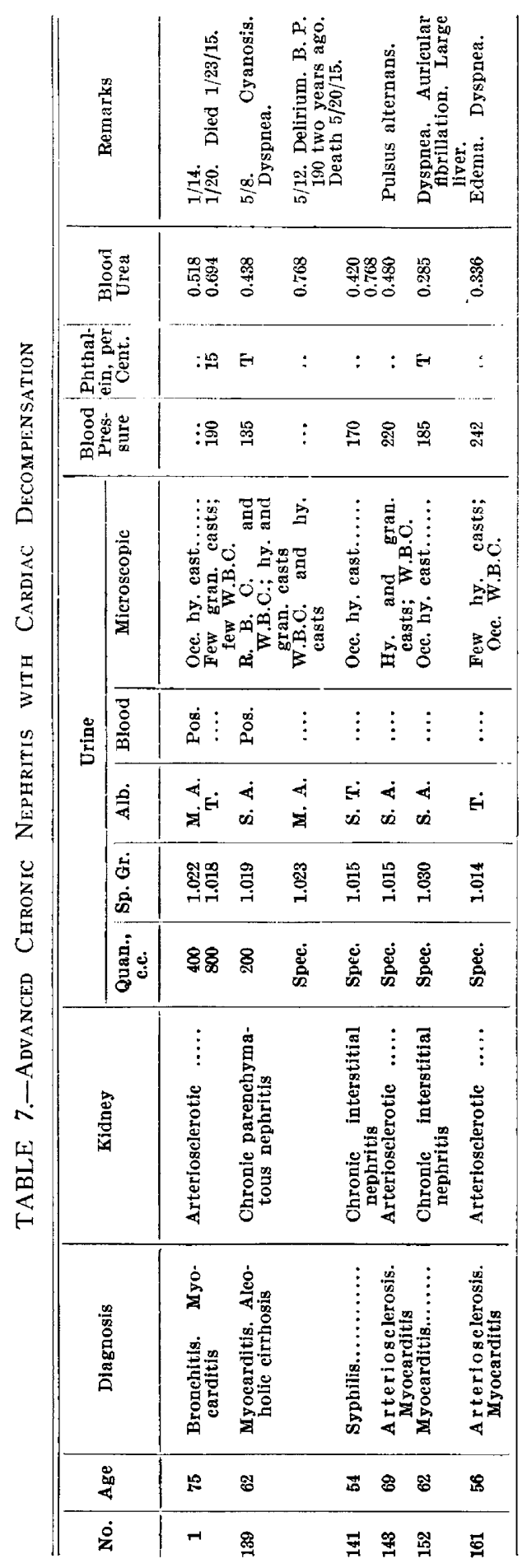




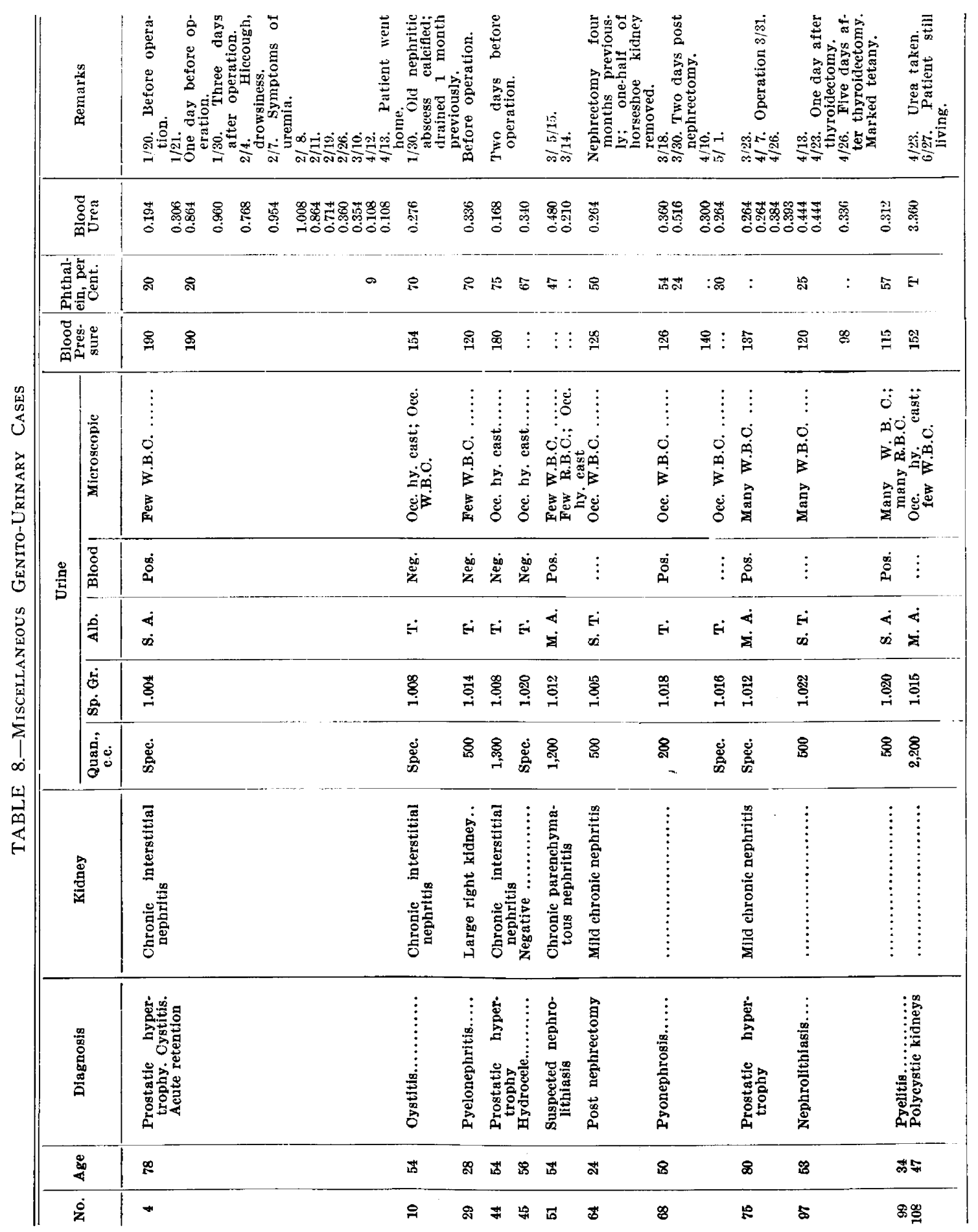




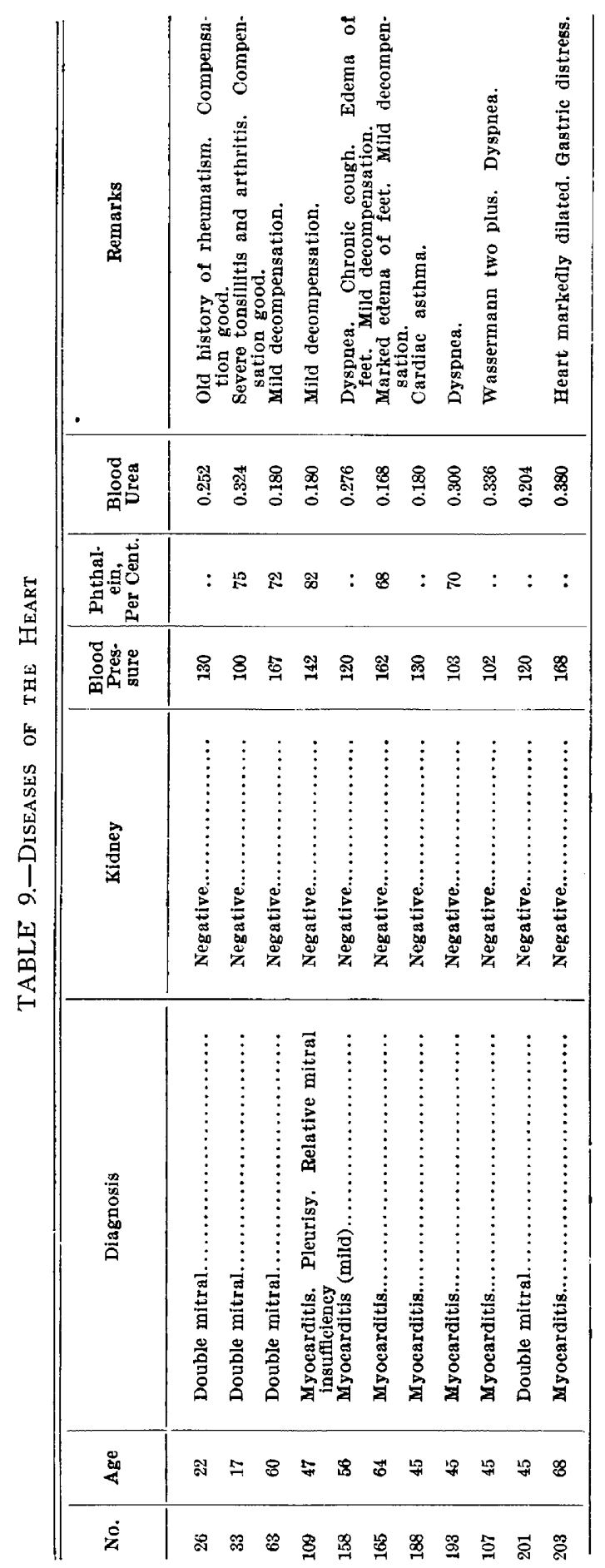

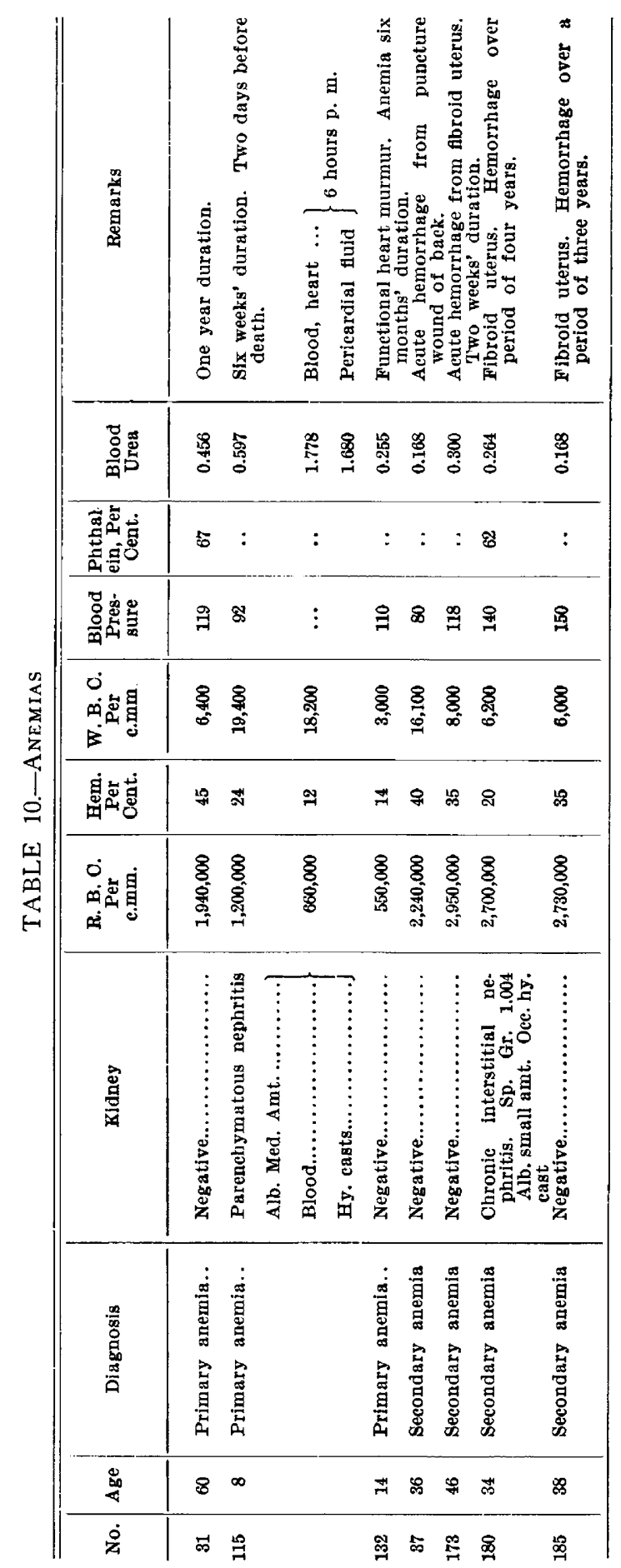


of the progressive decrease of blood urea to normal, while the phthalein excretion remained small ( 9 per cent.).

That a high urea can occur without uremic symptoms is shown in Case 134. This case of chronic interstitial nephritis had a blood urea of $1.080 \mathrm{gm}$. per liter.

One case of diabetic coma with chronic interstitial nephritis had $2.340 \mathrm{gm}$. per liter, probably as a terminal condition.

The cases on which a phthalein test was made practically all show a distinct decrease along with the rise in blood urea.

\section{ADVANCED CHRONIC NEPHRITIS WITH CARDIAC DECOMPENSATION}

The average blood urea in this series of cases was $0.523 \mathrm{gm}$. per liter, which is higher than the same group of cases without cardiar decompensation, and also distinctly increased above normal value. The blood pressure of all these patients was distinctly elevated. The phthalein was just a trace in two cases, 15 per cent. in another case. Two of the cases with the highest blood urea (0.694 and $0.768 \mathrm{gm}$. per liter) died shortly after the test was made. Case 141 with a urea of $0.768 \mathrm{gm}$. per liter was in a fairly good physical condition at time of observation. No normal values were obtained in this group of cases.

\section{MISCELLANEOUS GENITO-URINARY CASES}

Twelve miscellaneous cases have been recorded under Table 8. Three cases of prostatic hypertrophy were observed, each having a definite nephritis. One case showed a normal value; the others were increased. Case 4 is interesting in that it shows a rise of blood ure ${ }^{i}$ from 0.194 to $0.864 \mathrm{gm}$. per liter associated with a partial urinary retention progressing to a complete retention. After operation the patient had typical uremic symptoms with a blood urea of $1.008 \mathrm{gm}$. per liter. As the patient improved the blood urea dropped progressively until a normal value was reached (0.108 $\mathrm{gm}$. per liter). The patient was in fairly good condition at this time.

We found increased urea in cases of nephrolithiasis, pyelonephritis, and pyonephrosis, cystitis, and pyelitis. The cystitis was complicated with chronic interstitial nephritis.

We had under observation a very interesting case of polycystic kidneys (Case 108). Both kidneys were markedly enlarged, the excretion of phthalein was practically nil, and the patient was suffering from chronic uremia. The blood urea was $3.360 \mathrm{gm}$. per liter, which is the highest value we have obtained in any case. It is remarkable in that the patient is living, three months after the urea examination was made. 
DISEASES OF THE IIEART

Four cases of double mitral lesions were observed. Three showed normal blood urea. One case had a severe tonsillitis and arthritis and showed a slight increase in blood urea $(0.324 \mathrm{gm}$. per liter $)$. Four of the seven cases of myocarditis were slightly elevated. In no instance did the blood urea increase to $0.400 \mathrm{gm}$. per liter.

\section{ANEMIAS}

Rowntree and Fitz (1913) report a case of splenic anemia with polyserositis with a blood urea of $0.280 \mathrm{gm}$. per liter.

Tileston and Comfort (1914) obtained normal or only slightly raised blood ureas in two cases of secondary anemia due to hemor. rhage and in one case of Banti's disease. In two cases of hemolytic anemia they found marked retention, 0.597 and $0.790 \mathrm{gm}$. per liter.

We have studied three cases of hemolytic anemia (primary) and four of secondary anemia due to hemorrhage. Two of the cases of secondary anemia had a normal blood urea; the other two cases showed only a mild increase. Two cases of chronic pernicious anemia showed $0.456 \mathrm{gm}$. and $0.255 \mathrm{gm}$. per liter, respectively. Case 115 was a very acute pernicious anemia in a child, terminating fatally in six weeks. Two days before death the blood urea was $0.597 \mathrm{gm}$. per liter; six hours postmortem the urea in heart's blood was $1.778 \mathrm{gm}$. per liter. He developed a terminal nephritis with many hyaline and blood casts.

\section{LOBAR PNEUMONIA}

Tileston and Comfort (1914) report blood ureas on fourteen cases of lobar pneumonia. The highest value was $0.360 \mathrm{gm}$. per liter, the lowest $0.112 \mathrm{gm}$. per liter. They believed there was no relation between retention and prognosis. Foster (1915) found a rise in nonprotein nitrogen in lobar pneumonia exceptional and associated only with marked circulatory disturbance.

We made forty-two blood urea determinations on twenty cases of lobar pneumonia. These ranged from $0.120 \mathrm{gm}$. per liter to $1.044 \mathrm{gm}$. per liter, with an average of $0.405 \mathrm{gm}$. per liter. In thirty-six of the ureas the values were higher than normal; many of the cases showed a rather marked increase. Some of these patients were cyanosed at the time blood was taken but a number were not. Seventeen of the twenty cases ran a definite toxic nephritis, which probably helped to increase the blood urea. Only one case with a urea of over $0.6 \mathrm{gm}$. per liter recovered. We believe that in cases with marked increase a bad prognosis should be given. We found in cases of recovery the maximum increase was about the time of crisis, but most of oui cases even on the first and second day after onset showed some urea retention. For more details the reader is referred to Table 11. 


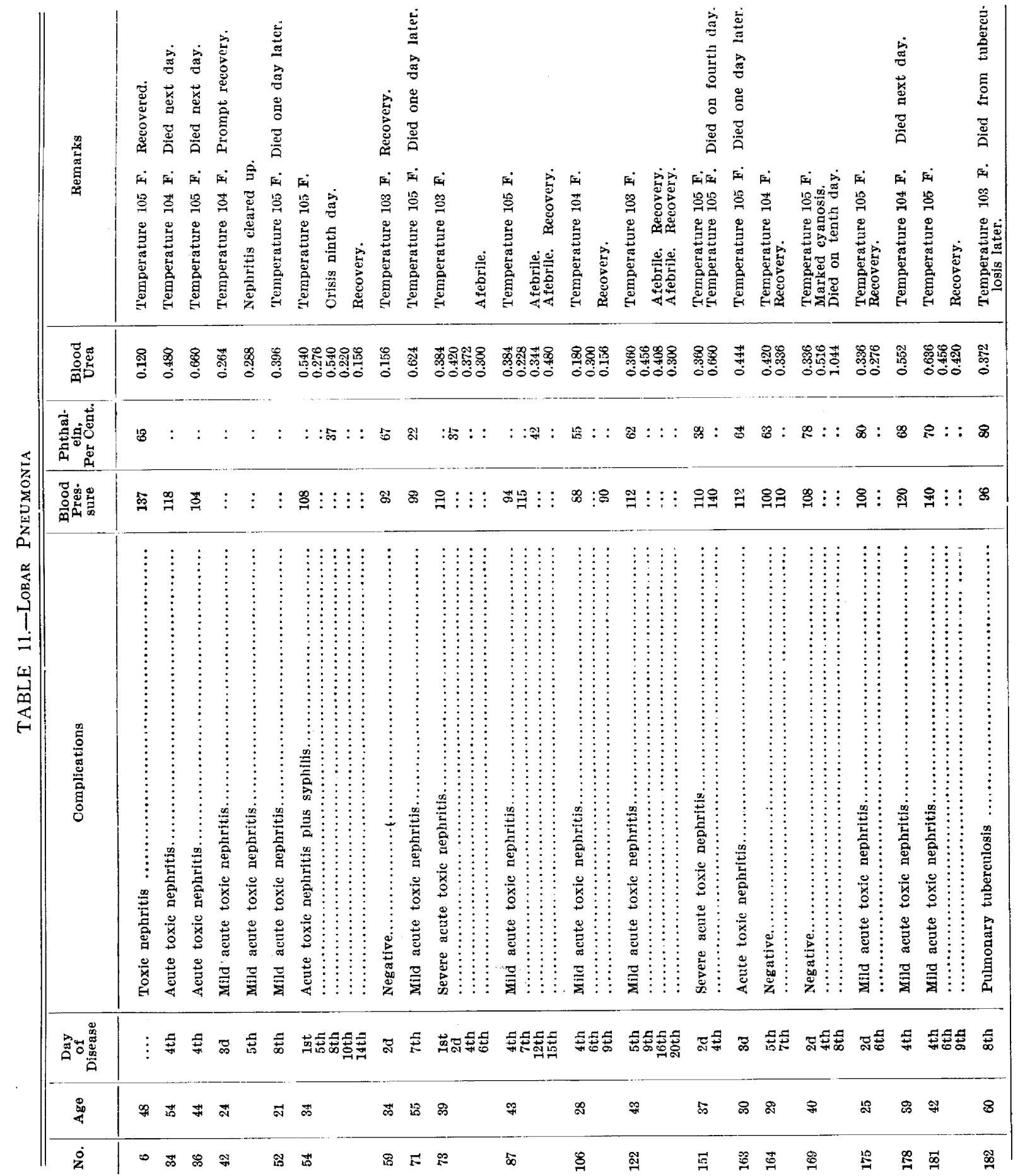



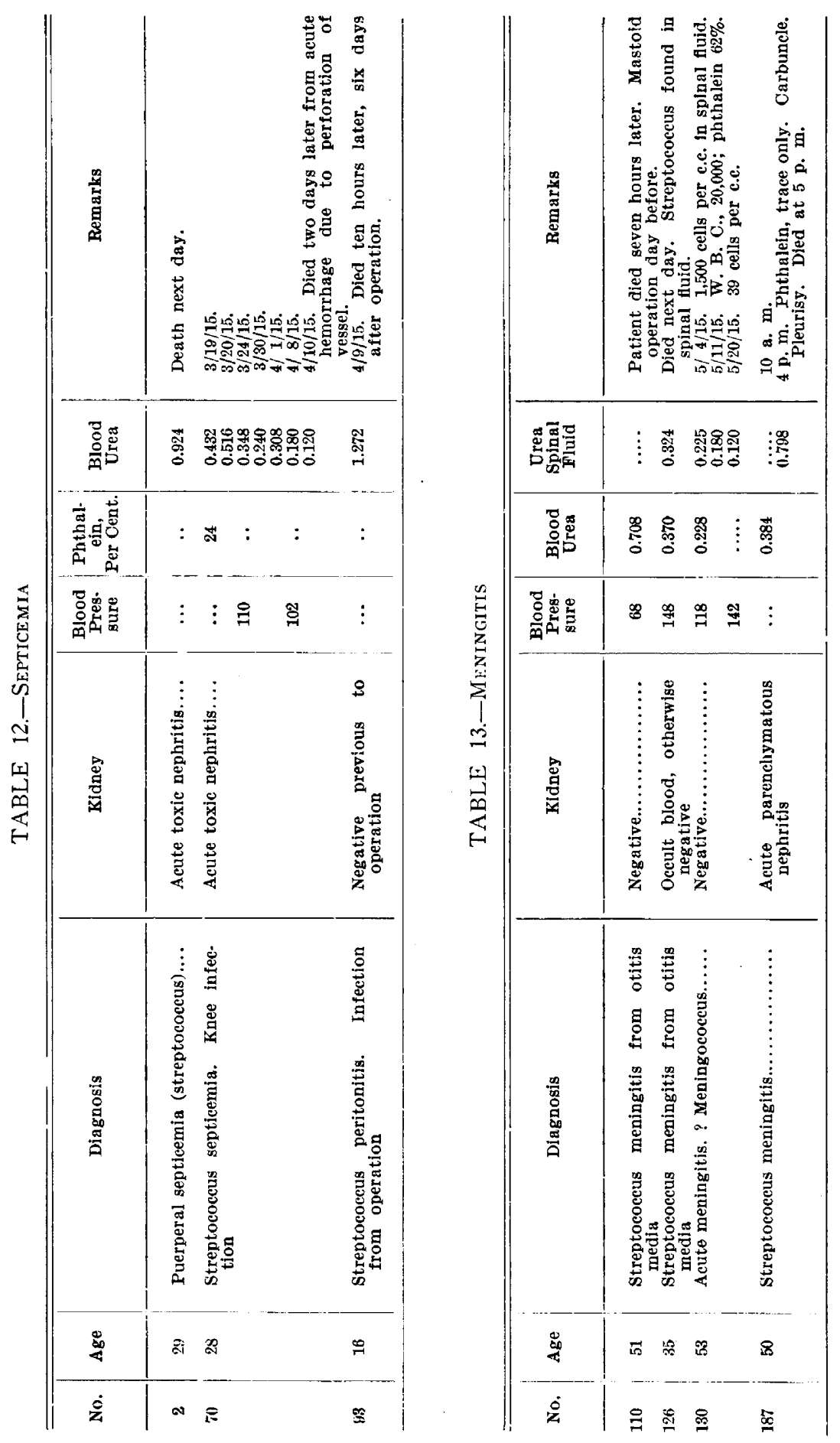


\section{SEPTICEMIA}

A single case of puerperal sepsis with recovery we find reported in the literature by Tileston and Comfort, with a normal blood urea.

Three cases of streptococcic septicemia came under our observation, all terminating fatally. Two of these patients developed severe acute toxic nephritis. The urine was not obtained from the third.

In Case 2 of puerperal septicemia the patient had a blood urea of $0.924 \mathrm{gm}$. per liter, and died within twenty-four hours; Case 93, general peritonitis, a patient with a blood urea of 1.272 , died within ten hours; Case 70 had a blood urea of $0.516 \mathrm{gm}$. per liter on March 20, 1915, which dropped progressively to $0.120 \mathrm{gm}$. per liter on April 10, 1915, when the patient died from acute hemorrhage.

\section{MENINGITIS}

Three cases of streptococcic meningitis and one case of meningococcic meningitis were observed. The three cases of streptococcic meningitis showed definite increase in the urea; that of meningococcic meningitis showed normal urea (Table 13).

\section{ROCKY MOUNTAIN SPOTTED FEVER}

Only one case of spotted fever was observed. This was in a patient on the sixth day after onset, with marked petechial eruption, mild delirium and cyanosis. The blood showed $0.690 \mathrm{gm}$. of urea per liter. At the time there was only a trace of albumin in the urine. The patient died two days later.

Table 14.-Rocky Mountain Spotten Fever

\begin{tabular}{c|c|c|c|c}
\hline \hline No. & Age & Urine & Blood Urea & Remarks \\
\cline { 2 - 4 } & $\mathbf{1 5 4}$ & Trace albumin $\ldots . . . \ldots$ & 0.690 & Died two days later. \\
\cline { 1 - 3 }
\end{tabular}

\section{SYPHILIS}

Folin and Denis in 1913 reported sixty-three cases. Of these 46 per cent. showed a moderate elevation in blood urea.

Tileston and Comfort (1914) observed eleven cases. Approximately 50 per cent. showed increase of blood urea. They found albumin and casts in practically all of their cases, and concluded that the kidney was affected in a considerable percentage of syphilitics. Nitrogen retention was more eyident in the tertiary stage, according to their observation.

Thirty-nine cases of demonstrable syphilis and four cases of clinically suspected syphilis are included in our series and the results are recorded in Table 15. 


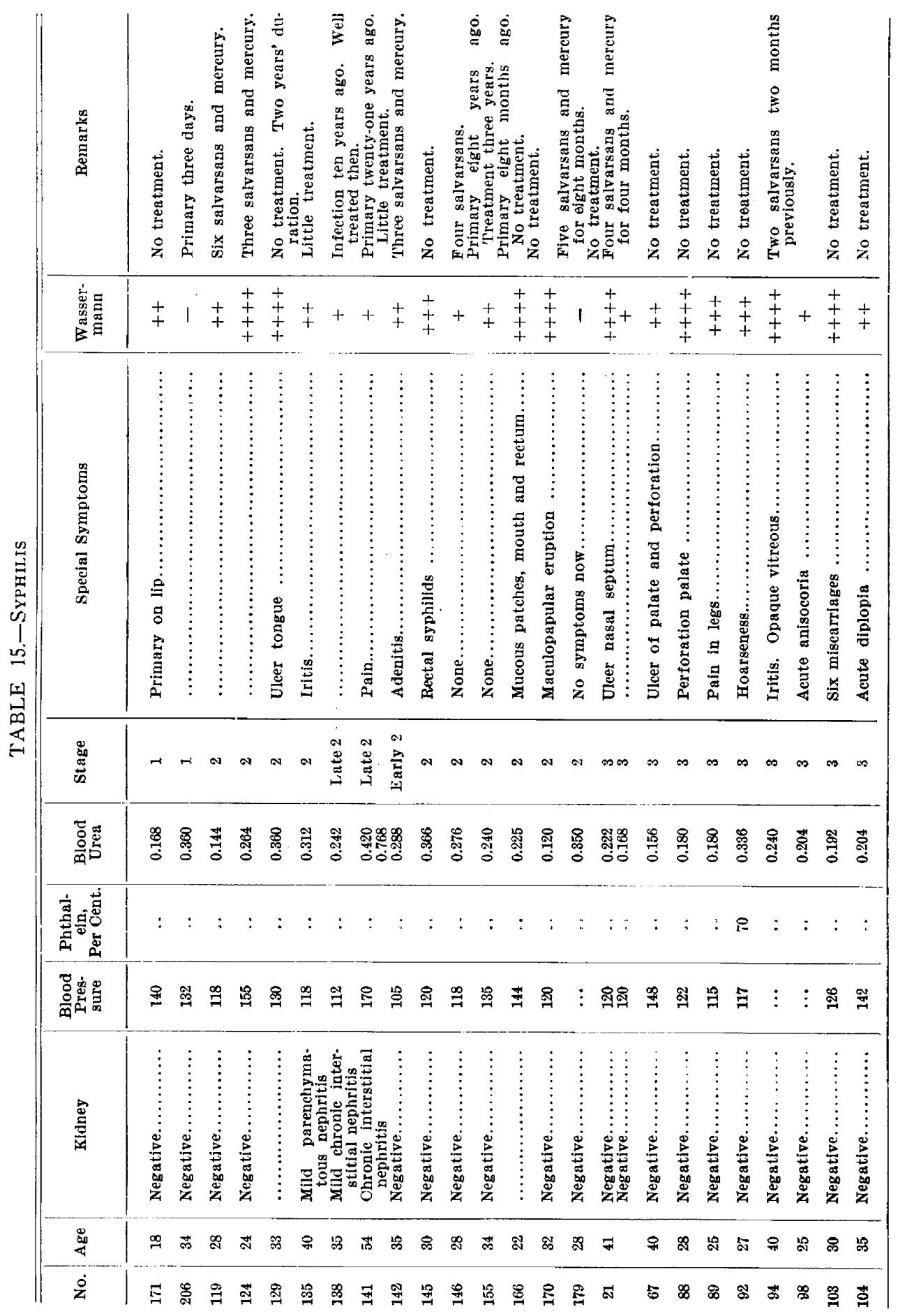




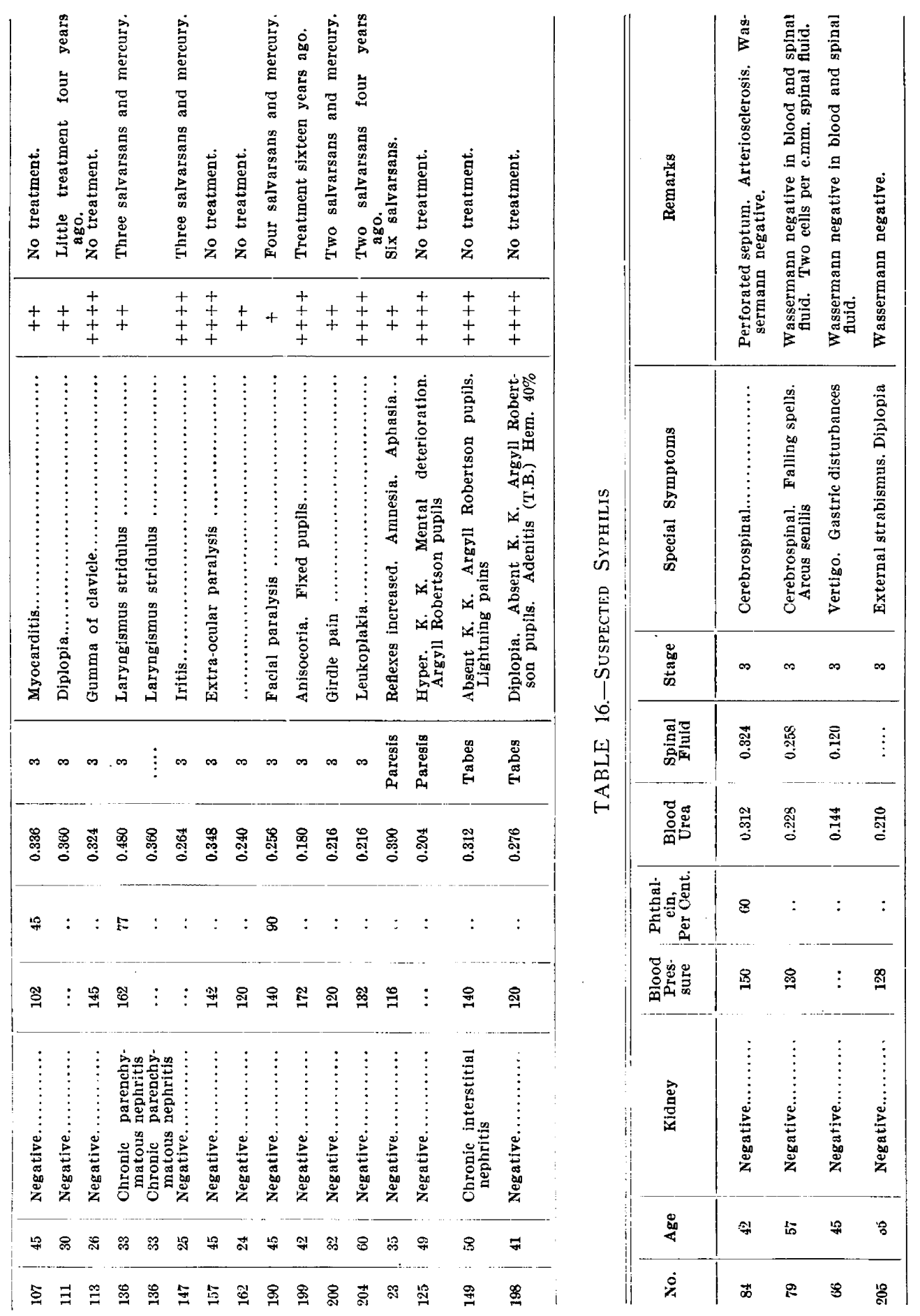


Two cases were primary lues and one of these showed an increase in blood urea. Neither case showed any evidence of kidney pathology.

There were thirteen cases in the secondary stage. Eight shower an elevation of blood urea (i. e., above 0.250 ). Three of these had a distinct nephritis. Five cases showed an increase above $0.300 \mathrm{gm}$. per liter, four of whom had practically no treatment for their syphilis.

Twenty cases of the tertiary stage were studied. Eight of these showed an increased urea. But two cases had evidence of a distinct nephritis. Four of the five patients in whom the urea was over $0.300 \mathrm{gm}$. per liter had received no treatment.

Paresis and tabes dorsalis were each observed in two instances. The urea was elevated in one paretic and in both cases of tabes. One case of tabes had an interstitial nephritis.

\section{SUMMARY}

To summarize our observations:

1. Twenty of the thirty-nine cases showed an elevated blood urea (approximately 50 per cent.) ; of the primary stage 50 per cent., secondary 62 per cent., tertiary 40 per cent., and quarternary 75 per cent.

2. But six cases had evidence of a nephritis.

3. Nearly 80 per cent. of the thirteen cases in whom the blood urea was over $0.300 \mathrm{gm}$. per liter had received no treatment.

4. No relation between the Wassermann test and the amount of blood urea can be drawn.

5. The highest urea was 0.768 , a patient who had acquired syphilis twenty years ago, and has now a chronic interstitial nephritis.

6. It is interesting to note that of the cases who received three or more salvarsans, but one was increased above $0.300 \mathrm{gm}$. per liter.

\section{PULMONARY TUBERCULOSIS}

A glance at Table 17 will show that in two cases out of seven, there was an increase in blood urea. Case 121, an acute miliary tuberculosis, with a severe acute toxic nephritis, had $0.600 \mathrm{gm}$. urea per liter, and terminated fatally. Case 123, a chronic advanced tuberculosis, was slightly raised $(0.288 \mathrm{gm}$. per liter $)$, and had a mild parenchymatous nephritis. Other authors have observed retention in cases of tuberculosis (Tileston and Comfort).

\section{DIABETES MELLITUS}

Seven cases of diabetes mellitus are included in our series (see Table 18). Five of these were complicated with chronic nephritis. Three of the cases showed definite increase in blood urea. They were all cases with nephritis. Case 184 had urea $0.336 \mathrm{gm}$. per liter on admission to the hospital. Two days later he developed coma and had a blood urea of $2.340 \mathrm{gm}$. per liter. He died the following day. 

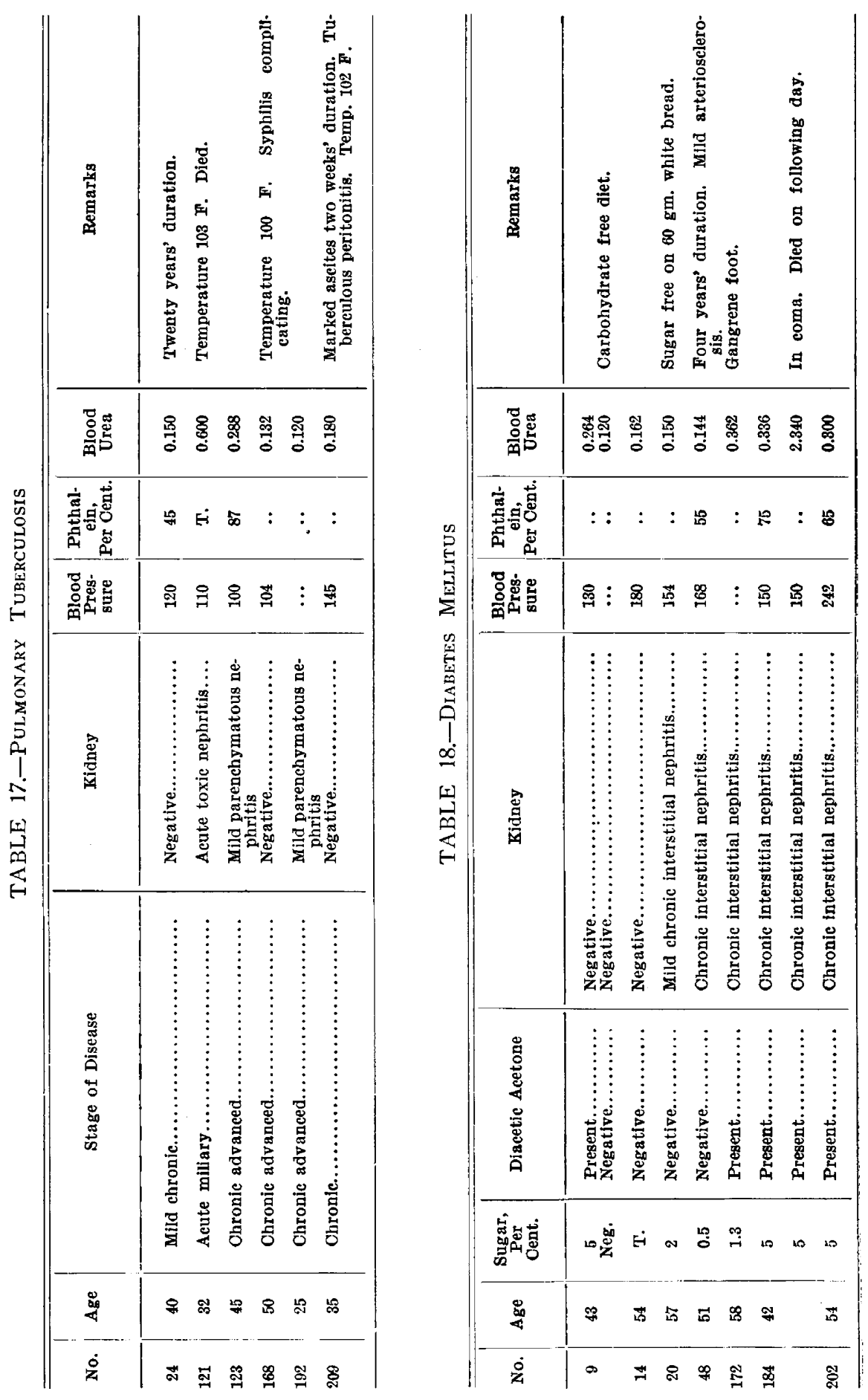


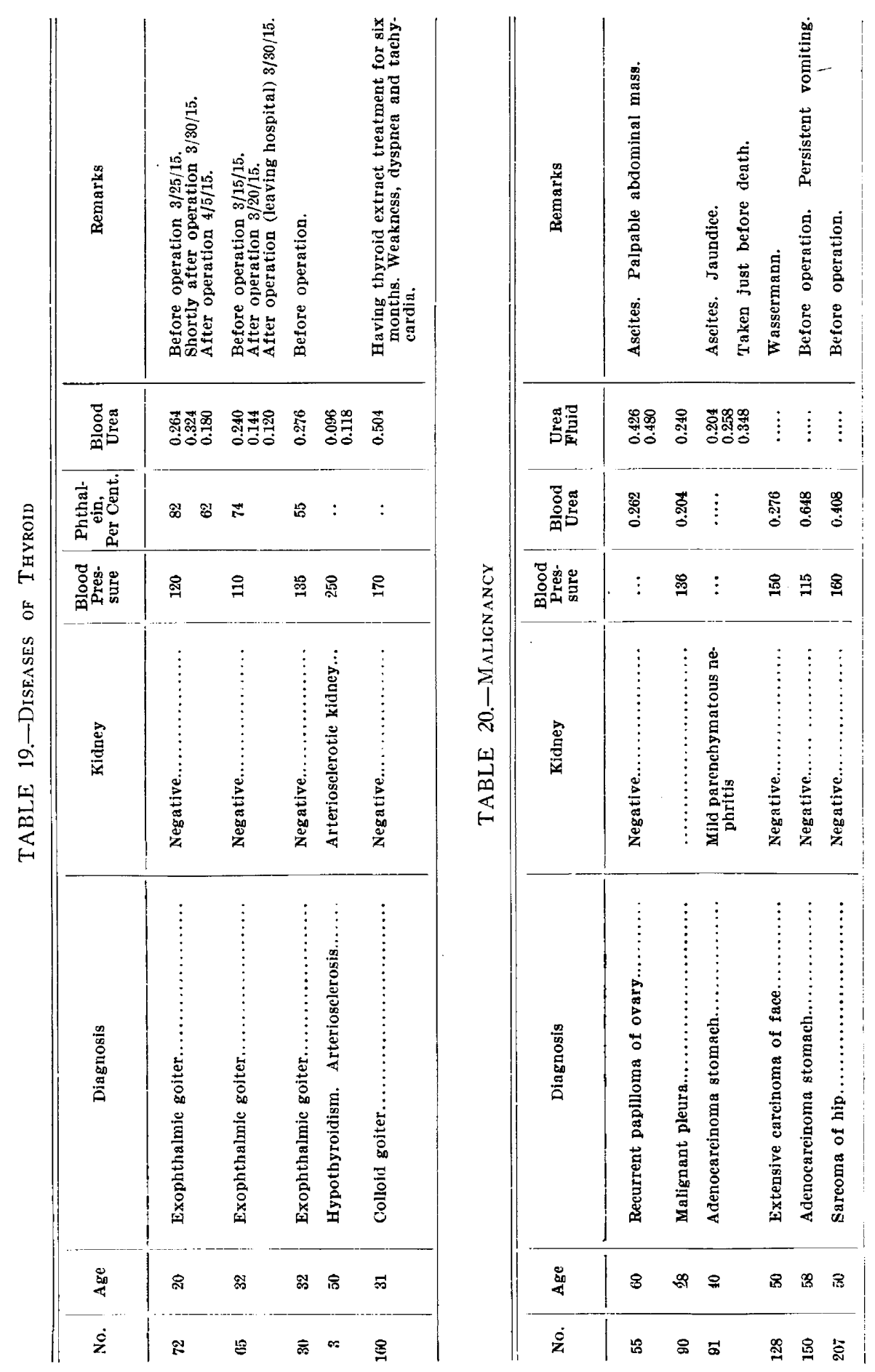




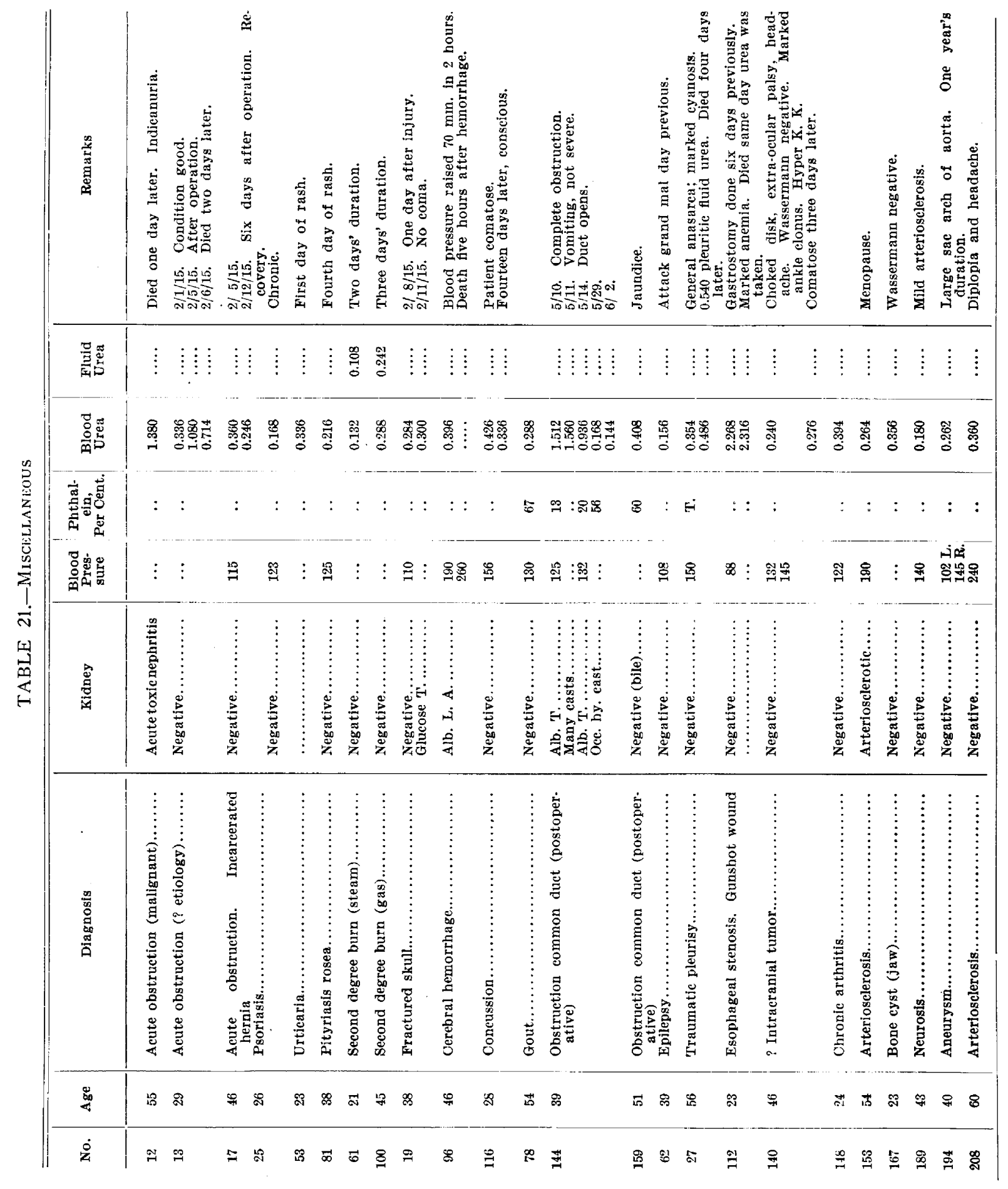


DISEASES OF THE THYROID

We made blood urea determinations on three cases of exophthalmic goiter. All showed a urea slightly above normal before operation. Following operation the urea dropped to normal. We studied only one case of myxedema. The patient had in addition marked arteriosclerosis. Two determinations of urea were made, both of which were slightly below normal.

Case 160 was a patient with a large colloid goiter who had taken thyroid extract for six months. He showed marked hyperthyroidism. His blood urea was increased to $0.504 \mathrm{gm}$. per liter.

The phenolsulphonephthalein output in all three cases of exophthalmic goiter was normal or slightly increased in amount.

\section{MALIGNANCY}

A series of six cases was studied, the results of which are shown in Table 20. Two cases show slight increase. Cases 150 and 207 show a distinct elevation, 0.648 and $0.408 \mathrm{gm}$. per liter, respectively. Neither case had any clinical evidence of nephritis. This observation is not in accord with the conclusion of Tileston and Comfort, who stated that no changes were met with in malignant disease which could not be ascribed to a complicating renal disease.

\section{MISCELLANEOUS}

We have studied twenty-four miscellaneous conditions. Four cases of intestinal obstruction had an increased blood urea. Cases 12 and 13 showed very high values, 1.380 and $1.080 \mathrm{gm}$. per liter, respectively. One case of obstructed bile duct, complicated with parenchymatous nephritis, showed $1.560 \mathrm{gm}$. per liter, but dropped promptly to normal as soon as the obstruction was relieved. Case 112 gave marked urea increase, $2.311 \mathrm{gm}$. per liter. The patient had an esophageal stenosis.

Slightly raised values were found in urticaria, fracture of the skull, cerebral hemorrhage, cerebral concussion, traumatic pleurisy, bone cyst, arteriosclerosis, and chronic arthritis. Normal values were obtained in psoriasis, pityriasis rosea, epilepsy, and a functional neurosis.

THE UREA CONTENT OF BODY FLUIDS

A most excellent summary of the literature on the subject is included in the work of Soper and Granat (1914). To that article the reader is referred.

Soper and Granat studied the urea content in the spinal fluid in ninety-seven cases. They found that the amount of the urea in the spinal fluid usually agreed with that in the blood. Most of the variations were due to the difference in time of taking of the fluids. 
TABLE 22.-URea Content in Body Fluids

\begin{tabular}{|c|c|c|c|c|}
\hline No. & Diagnosis & Fluid & $\begin{array}{l}\text { Fluid } \\
\text { Urea }\end{array}$ & $\begin{array}{c}\text { Blood } \\
\text { Urea }\end{array}$ \\
\hline 51 & 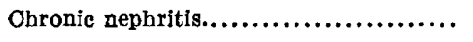 & Spinal............. & 0.166 & 0.210 \\
\hline 84 & 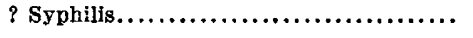 & Spinal............. & 0.324 & 0.312 \\
\hline 74 & Paresis................................ & Spinal............. & 0.270 & $\cdots \cdots$ \\
\hline 54 & Syphilis............................ & Spinal............. & 0.390 & 0.540 \\
\hline 79 & Syphilis.......................... & Spinal............ & 0.258 & 0.228 \\
\hline 66 & 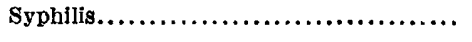 & Spinal............. & 0.120 & 0.144 \\
\hline 125 & 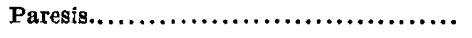 & Spinal............. & 0.204 & 0.198 \\
\hline 126 & Meningitis........................... & Spinal............. & 0.324 & 0.370 \\
\hline 130 & 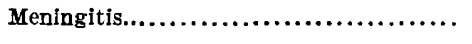 & Spinal............. & 0.255 & 0.288 \\
\hline 140 & 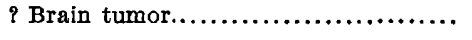 & Spinal............ & 0.204 & 0.240 \\
\hline 130 & 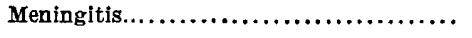 & Spinal............. & 0.180 & $\cdots$ \\
\hline 162 & Cerebrospirıal syphilis................ & Spinal............ & 0.198 & 0.240 \\
\hline 130 & Meningitis........................... & Spinal............. & 0.120 & $\cdots \cdot$ \\
\hline 183 & Ohronic nephritis..................... & Spinal............. & 0.240 & 0.204 \\
\hline 187 & 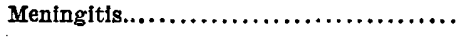 & Spinal............. & 0.798 & 0.384 \\
\hline 191 & 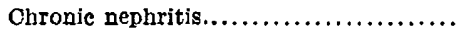 & Spinal............ & 0.596 & 0.396 \\
\hline 198 & Tabes dorsalis....... & Spinal....... & 0.264 & 0.276 \\
\hline 89 & Syphilis.............................. & Spinal............. & 0.216 & 0.180 \\
\hline 210 & 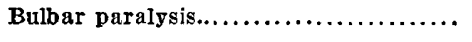 & Spinal............ & 0.120 & $\cdots \cdots$ \\
\hline 55 & Ovarian tumor (malignant)............ & Peritoneal.......... & 0.426 & 0.262 \\
\hline 91 & Carcinoma of stomach................ & Peritoneal......... & 0.204 & $\cdots \cdots$ \\
\hline 91 & Carcinoma of stomach................ & Peritoneal......... & 0.258 & $\cdots \cdots$ \\
\hline 91 & 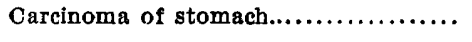 & Peritoneal.......... & 0.348 & $\cdots \cdots$ \\
\hline 55 & 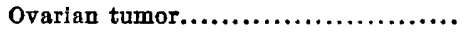 & Peritoneal......... & 0.480 & $\cdots \cdots$ \\
\hline 209 & Tubercular peritonitis................. & Peritoneal......... & 0.180 & 0.180 \\
\hline 57 & 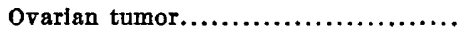 & Oyst............... & 0.432 & 0.233 \\
\hline 131 & 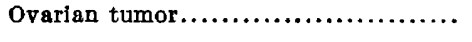 & Cyst............. & 0.216 & 0.192 \\
\hline 137 & Ovarian tumor..... & Oyst.............. & 0.168 & 0.156 \\
\hline 45 & Hydrocele.... & $\cdots \cdots \cdots \cdots \cdots \cdots \cdots$ & 0.276 & 0.340 \\
\hline 120 & Hydrocele............................. & $\cdots \cdots \cdots \cdots \cdots \cdots$ & 0.484 & $\cdots \cdots$ \\
\hline 61 & Second degree burn................... & Vesicle........... & 0.108 & 0.132 \\
\hline 100 & Second degree burn.................... & Vesicle............ & 0.242 & 0.288 \\
\hline 27 & Pleurisy..... & Pleural............ & 0.540 & 0.486 \\
\hline 90 & Malignant pleura..................... & Pleural............ & 0.240 & 0.204 \\
\hline 115 & 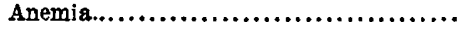 & Pericardial......... & 1.680 & 1.778 \\
\hline 211 & Gonorrheal arthritis..................... & Joint fluid.......... & 0.240 & 0.240 \\
\hline
\end{tabular}


TABLE 23.-Phthaleins

\begin{tabular}{|c|c|c|c|c|c|}
\hline $\begin{array}{l}\text { Oase } \\
\text { Number }\end{array}$ & $\begin{array}{c}\text { Per Cent. } \\
\text { Phthalein } \\
2 \text { Hrs. }\end{array}$ & $\begin{array}{c}\text { Blood } \\
\text { Urea }\end{array}$ & $\begin{array}{c}\text { Oase } \\
\text { Number }\end{array}$ & $\begin{array}{l}\text { Per Cent. } \\
\text { Phthalein } \\
2 \text { Hrs. }\end{array}$ & $\underset{\text { Urea }}{\text { Blood }}$ \\
\hline 196 & 65 & 0.108 & 202 & 65 & 0.306 \\
\hline 41 & 82 & 0.120 & 29 & 70 & 0.306 \\
\hline 6 & 65 & 0.120 & 84 & 60) & 0.312 \\
\hline $19 \%$ & 70 & 0.120 & 99 & 57 & 0.312 \\
\hline 40 & 67 & 0.156 & 80 & 60 & 0.326 \\
\hline 59 & 67 & 0.156 & 33 & 75 & 0.324 \\
\hline 137 & 82 & 0.156 & 85 & 42 & 0.324 \\
\hline$T$ & 65 & $0.16 \mathrm{j}$ & 114 & 80 & 0.324 \\
\hline 165 & 68 & 0.168 & 92 & 70 & 0.336 \\
\hline 144 & 56 & 0.168 & $10 \%$ & 45 & 0.336 \\
\hline 38 & 72 & 0.168 & 116 & 67 & 0.336 \\
\hline 39 & 87 & 0.168 & 169 & 78 & 0.336 \\
\hline 44 & 75 & 0.168 & 175 & 80 & 0.336 \\
\hline 48 & 55 & 0.144 & 156 & 75 & 0.336 \\
\hline 5 & 15 & 0.180 & 184 & 75 & 0.336 \\
\hline 60 & 40 & 0.180 & 45 & 67 & 0.340 \\
\hline 63 & 72 & 0.180 & 27 & $\mathbf{T}$ & 0.354 \\
\hline 106 & 55 & 0.180 & 68 & 54 & 0.360 \\
\hline 109 & 82 & 0.180 & 95 & 37 & 0.360 \\
\hline 132 & 66 & 0.182 & 122 & 62 & 0.360 \\
\hline 58 & 50 & 0.192 & 151 & 38 & 0.360 \\
\hline 131 & 68 & 0.192 & 136 & 77 & 0.360 \\
\hline 125 & 15 & 6.198 & 182 & 80 & 0.372 \\
\hline 183 & 67 & 0.204 & 76 & 50 & 0.396 \\
\hline 195 & 50 & 0.204 & 28 & 55 & 0.408 \\
\hline 83 & 60 & 0.216 & 150 & 60 & 0.408 \\
\hline 82 & 42 & 0.222 & 73 & 37 & 0.420 \\
\hline 162 & 73 & 0.240 & 164 & 63 & .0 .420 \\
\hline 105 & 70 & 0.242 & 70 & 40. & 0.432 \\
\hline 176 & 82 & 0.252 & 139 & $\mathbf{T}$ & 0.438 \\
\hline 190 & 95 & 0.256 & 163 & 64 & 0.444 \\
\hline 130 & 65 & 0.228 & 31 & 67 . & 0.456 \\
\hline 64 & 50 & 0.264 & 97 & 25 & 0.444 \\
\hline 71 & 82 & 0.264 & 51 & 47 & $0.4 \& 0$ \\
\hline 101 & 65 & 0.264 & 156 & 38 & 0.516 \\
\hline 68 & 30 & 0.264 & 54 & 37 & 0.540 \\
\hline 180 & 62 & 0.264 & 105 & 60 & 0.546 \\
\hline 20 & 55 & 0.276 & 178 & 68 & 0.552 \\
\hline
\end{tabular}


TABLE 23--Phthalfins--(Continued)

\begin{tabular}{|c|c|c|c|c|c|c|}
\hline $\begin{array}{l}\text { Case } \\
\text { Number }\end{array}$ & $\begin{array}{l}\text { Per Cent. } \\
\text { Phthalein } \\
2 \text { Hrs. }\end{array}$ & $\begin{array}{l}\text { Blood } \\
\text { Urea }\end{array}$ & & $\begin{array}{c}\text { Case } \\
\text { Number }\end{array}$ & $\begin{array}{c}\text { Per Cent. } \\
\text { Phthalein } \\
2 \text { Hrs. }\end{array}$ & $\begin{array}{c}\text { Blood } \\
\text { Urea }\end{array}$ \\
\hline 32 & 63 & 0.270 & & 121 & $\mathrm{~T}$ & 0.600 \\
\hline 10 & 70 & 0.276 & 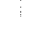 & 71 & 22 & 0.621 \\
\hline 35 & 65 & 0.280 & & 181 & 70 & 0.636 \\
\hline 50 & 77 & 0.288 & & 156 & 50 & 0.672 \\
\hline 78 & 67 & 0.288 & & 1 & 15 & 0.694 \\
\hline 87 & 42 & 0.288 & : & 156 & 26 & 0.720 \\
\hline 123 & 87 & 0.288 & 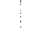 & 144 & 20 & 0.936 \\
\hline 152 & $\mathbf{T}$ & 0.285 & & 4 & 20 & 1.008 \\
\hline 11 & 95 & 0.291 & & 144 & 13 & 1.560 \\
\hline$\beth 93$ & 70 & 0.300 & 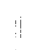 & 108 & $\mathbf{T}$ & 3.360 \\
\hline
\end{tabular}

They quote the work of Javal as establishing the fact that the urea content of body fluids, edema, pleural and ascitic, equals in amount the blood urea. They found the normal urea in spinal fluid between 0.01 per cent. and 0.05 per cent.

Cullen and Ellis ${ }^{36}$ (1915) have shown that when the blood and spinal fluid are drawn at about the same time the difference in the amount of urea in the two fluids is rarely greater than $2 \mathrm{mg}$. per 100 c.c.

We have made comparative urea determinations on the body fluids and blood of twenty-eight different patients. Of these nineteen were spinal and six were peritoneal fluids. Table 23 shows the results, and they will be seen to correspond closely with those obtained by Soper and Granat. In the main the blood urea equals the fluid urea. Cases 54, 55, 57, 187 and 191 show rather marked differences. The fluids and blood from Cases 54, 55 and 57 were taken within a few minutes of each other. The fluids from Cases 55 and 57 were from very thick-walled ovarian cysts. The fluids from Cases 187 and 191 were taken at different times from the blood.

\section{CONCLUSIONS}

1. In the normal fasting adult the blood urea varied from 0.108 to $0.252 \mathrm{gm}$. per liter.

2. The majority of cases of acute nephritis show an increased urea.

3. In mild chronic nephritis there is a normal or slightly elevated amount of blood urea. Cases of advanced chronic nephritis have a distinct increase. The effect of an associated cardiac decompensation is to further elevate the blood urea.

36. Cullen and Ellis: Jour. Biol. Chem., 1915, xx, 511. 
TABLE 24.-Blood Pressures*

\begin{tabular}{|c|c|c|c|c|c|c|c|}
\hline $\begin{array}{l}\text { Case } \\
\text { No. }\end{array}$ & Age & $\begin{array}{c}\text { Blood } \\
\text { Pressure }\end{array}$ & $\begin{array}{c}\text { Blood } \\
\text { Urea }\end{array}$ & $\begin{array}{l}\text { Oase } \\
\text { No. }\end{array}$ & Age & $\begin{array}{c}\text { Blood } \\
\text { Preseure }\end{array}$ & $\begin{array}{c}\text { Blood } \\
\text { Urea }\end{array}$ \\
\hline 110 & 51 & 68 & 0.708 & 122 & 43 & 112 & 0.360 \\
\hline 37 & 36 & 80 & 0.168 & 122 & 43 & 112 & 0.456 \\
\hline 106 & 28 & 88 & 0.180 & 138 & 35 & 112 & 0.242 \\
\hline 112 & 23 & 88 & 2.316 & 150 & 58 & 112 & 0.648 \\
\hline 106 & 28 & 90 & 0.156 & 163 & 30 & 112 & 0.444 \\
\hline 59 & 34 & 92 & 0.156 & 17 & 46 & 115 & 0.246 \\
\hline 115 & 8 & 92 & 0.596 & 89 & 25 & 115 & 0.180 \\
\hline 87 & 43 & 94 & 0.384 & 99 & 34 & 115 & 0.312 \\
\hline 182 & 60 & 96 & 0.372 & 23 & 35 & 116 & 0.390 \\
\hline 97 & 53 & 98 & 0.336 & 47 & 24 & 116 & 0.192 \\
\hline 123 & 45 & 100 & 0.288 & 92 & 27 & 117 & 0.3836 \\
\hline 122 & 43 & 100 & 0.408 & 34 & 48 & 118 & 0.480 \\
\hline 164 & 29 & 100 & 0.420 & 119 & 28 & 118 & 0.144 \\
\hline 33 & 17 & 100 & 0.324 & 130 & 53 & 118 & 0.228 \\
\hline 38 & 23 & 100 & 0.168 & 135 & 40 & 118 & 0.312 \\
\hline 58 & 22 & 100 & 0.192 & 146 & .. & 118 & 0.276 \\
\hline 39 & 21 & 102 & 0.168 & 173 & 46 & 118 & 0.300 \\
\hline 70 & 28 & 102 & 0.120 & 31 & 60 & 119 & 0.456 \\
\hline 107 & 45 & 102 & 0.336 & 32 & 20 & 119 & 0.270 \\
\hline 175 & 25 & 102 & 0.336 & 24 & 40 & 120 & 0.150 \\
\hline 183 & . 45 & 103 & 0.300 & 29 & .. & 120 & 0.336 \\
\hline 168 & 50 & 104 & 0.132 & 21 & 41 & 120 & 0.222 \\
\hline 36 & 44 & 104 & 0.660 & 72 & 20 & 120 & 0.264 \\
\hline 142 & .. & 105 & 0.288 & 95 & 27 & 120 & 0.360 \\
\hline 137 & 25 & 106 & 0.156 & 97 & 53 & 120 & 0.444 \\
\hline 54 & 34 & 108 & 0.540 & 101 & 55 & 120 & 0.264 \\
\hline 62 & 89 & 108 & 0.156 & 145 & .. & 120 & 0.336 \\
\hline 169 & 40 & 108 & 0.338 & 158 & 56 & 120 & 0.276 \\
\hline 19 & 88 & 110 & 0.884 & 162 & 24 & 120 & 0.240 \\
\hline 35 & 23 & 110 & 0.280 & 170 & 32 & 120 & 0.120 \\
\hline 69 & 21 & 110 & 0.108 & 178 & 39 & 120 & 0.552 \\
\hline 70 & 28 & 110 & 0.432 & 195 & 20 & 120 & 0.204 \\
\hline 73 & 34 & 110 & 0.420 & 197 & 23 & 120 & 0.120 \\
\hline 121 & .. & 110 & 0.600 & 198 & 41 & 120 & 0.276 \\
\hline 133 & 14 & 110 & 0.255 & 200 & 32 & 120 & 0.216 \\
\hline 161 & 37 & 110 & 0.360 & 201 & . & 120 & 0.204 \\
\hline 122 & 43 & 110 & 0.300 & 40 & 21 & 122 & 0.156 \\
\hline 11 & . & 112 & 0.288 & 41 & 21 & 122 & 0.120 \\
\hline
\end{tabular}

- Blood pressures are systolic. 
TABLE 24.-Blood Pressures *-(Continued)

\begin{tabular}{|c|c|c|c|c|c|c|c|}
\hline $\begin{array}{l}\text { Case } \\
\text { No. }\end{array}$ & Age & $\underset{\text { Pressure }}{\text { Blood }}$ & $\underset{\text { Urea }}{\text { Blood }}$ & $\begin{array}{l}\text { Oase } \\
\text { No. }\end{array}$ & $\mathbf{A g} \theta$ & $\underset{\text { Pressure }}{\text { Blood }}$ & $\begin{array}{c}\text { Blood } \\
\text { Urea }\end{array}$ \\
\hline 50 & 67 & 122 & 0.288 & 151 & 37 & 140 & 0.660 \\
\hline 88 & 28 & 122 & 0.180 & 171 & 18 & 140 & 0.168 \\
\hline 148 & $\cdots$ & 122 & 0.394 & 181 & 42 & 140 & 0.636 \\
\hline 176 & .. & 122 & 0.252 & 189 & 43 & 140 & 0.180 \\
\hline 25 & 26 & 123 & 0.168 & 190 & 45 & 140 & 0.256 \\
\hline 81 & 38 & 125 & 0.216 & 104 & .. & 142 & 0.204 \\
\hline 144 & 39 & 125 & 1.512 & 109 & 47 & 142 & 0.180 \\
\hline 60 & 22 & 126 & 0.180 & 130 & 53 & 142 & 0.180 \\
\hline 68 & 50 & 126 & 0.360 & 157 & 45 & 142 & 0.348 \\
\hline 108 & .. & 126 & 0.192 & 166 & 22 & 144 & 0.225 \\
\hline 205 & 35 & 128 & 0.210 & 113 & 26 & 145 & 0.324 \\
\hline 129 & 33 & 130 & 0.360 & 140 & 46 & 145 & 0.276 \\
\hline 156 & 32 & 130 & 0.672 & 194 & .. & 145 & 0.264 \\
\hline 26 & 22 & 130 & 0.252 & 200 & 35 & 145 & 0.180 \\
\hline 78 & 54 & 130 & 0.288 & 67 & 40 & 148 & 0.156 \\
\hline 79 & 57 & 130 & 0.228 & 126 & 35 & 148 & 0.370 \\
\hline 102 & 35 & 130 & 0.336 & 7 & 72 & 150 & 0.084 \\
\hline 140 & 46 & 132 & 0.240 & 22 & 16 & 150 & 0.372 \\
\hline 139 & 62 & 132 & 0.438 & 84 & 42 & 150 & 0.312 \\
\hline 144 & 39 & 132 & 1.560 & 128 & 50 & 150 & 0.276 \\
\hline 9 & 43 & 130 & 0.264 & 184 & 42 & 150 & 0.336 \\
\hline 188 & 45 & 130 & 0.180 & 108 & 47 & 152 & 3.360 \\
\hline 196 & 26 & 132 & 0.108 & 27 & 56 & 150 & 0.354 \\
\hline 206 & 34 & 132 & 0.360 & 16 & 33 & 154 & 0.324 \\
\hline 204 & 60 & 132 & 0.216 & 20 & 67 & 154 & 0.150 \\
\hline 28 & 33 & 134 & 0.408 & 10 & 54 & 154 & 0.276 \\
\hline 127 & 65 & 134 & 0.240 & 131 & 37 & 154 & 0.192 \\
\hline 156 & 32 & 134 & 0.720 & 124 & 24 & 155 & 0.264 \\
\hline 8 & 54 & 135 & 0.210 & 15 & 27 & 156 & 0.228 \\
\hline 30 & 32 & 135 & 0.276 & 116 & 28 & 156 & 0.426 \\
\hline 155 & 34 & 135 & 0.240 & 207 & 50 & 160 & 0.408 \\
\hline 90 & 28 & 136 & 0.204 & 134 & 47 & 162 & 1.080 \\
\hline 6 & 48 & 137 & 0.120 & 136 & 33 & 162 & 0.480 \\
\hline 75 & 80 & 137 & 0.264 & 165 & 64 & 162 & 0.168 \\
\hline 105 & 47 & 188 & 0.546 & 48 & 51 & 168 & 0.144 \\
\hline 180 & 34 & 138 & 0.264 & 114 & 60 & 168 & 0.324 \\
\hline 149 & 50 & 140 & 0.312 & 203 & 68 & 168 & 0.380 \\
\hline 68 & 50 & 140 & 0.264 & 86 & 46 & 170 & 0.348 \\
\hline
\end{tabular}

Downloaded From: http://archinte.jamanetwork.com/ by a New York University User on 05/30/2015 
TABLE 24.-Blood Pressures *-(Continued $)$

\begin{tabular}{|c|c|c|c|c|c|c|c|}
\hline $\begin{array}{l}\text { Case } \\
\text { No. }\end{array}$ & Age & $\begin{array}{c}\text { Plood } \\
\text { Pressure }\end{array}$ & $\begin{array}{c}\text { Blood } \\
\text { Urea }\end{array}$ & $\begin{array}{l}\text { Case } \\
\text { No. }\end{array}$ & Age & $\begin{array}{c}\text { Blood } \\
\text { Pressure }\end{array}$ & $\begin{array}{l}\text { Blood } \\
\text { Urea }\end{array}$ \\
\hline 141 & 54 & 170 & 0.420 & 90 & 46 & 190 & 0.396 \\
\hline 160 & 31 & 170 & 0.504 & 153 & 54 & 190 & 0.264 \\
\hline 199 & 42 & 172 & 0.180 & 191 & 58 & 204 & 0.396 \\
\hline 47 & .. & 178 & 0.242 & 85 & 60 & 208 & 0.324 \\
\hline 14 & 57 & 180 & 0.150 & 143 & 60 & 220 & 0.480 \\
\hline 44 & 56 & 180 & 0.168 & 18 & 55 & 230 & 0.276 \\
\hline 132 & 46 & 180 & 0.182 & 56 & 65 & 240 & 0.414 \\
\hline 105 & $4 \overline{7}$ & 180 & 0.249 & 208 & 60 & 240 & 0.360 \\
\hline 152 & 69 & 185 & 0.285 & 161 & 56 & 242 & 0.336 \\
\hline 174 & 67 & 186 & 0.264 & 22 & 54 & 242 & 0.300 \\
\hline$\ddot{i}$ & 75 & 190 & 0.694 & 3 & 50 & 250 & 0.096 \\
\hline 4 & 78 & 190 & 1.008 & 5 & 26 & 250 & 0.240 \\
\hline $46 j$ & 55 & 190 & 0.288 & 76 & 29 & 250 & 0.396 \\
\hline
\end{tabular}

4. A high value occurring with a transient mechanical obstruction of the urinary tract does not necessarily mean a bad prognosis.

5. In polycystic kidneys, with a very large amount of blood urea, and low phthalein excretion, the outcome may not be immediately fatal.

6. The majority of cases of lobar pneumonia have a raised value. A bad prognosis should be given in those cases which show considerable increase.

7. Approximately one-half of the cases of syphilis show a distinct elevation.

8. In exophthalmic goiter there is an increase, and in myxedema, a decrease in blood urea.

9. In primary anemia, nephrolithiasis, pyelonephritis, pyonephrosis, septicemia, streptococcic meningitis, Rocky Mountain spotted fever, pulmonary tuberculosis, diabetic coma, intestinal obstruction, malignancy, and common duct obstruction, we find a definite increase in most of the cases.

10. A slight elevation occurs in valvular heart lesions, myocarditis, secondary anemia, urticaria, fractured skull, cerebral hemorrhage, concussion, bone cyst, traumatic pleurisy, arteriosclerosis and chronic arthritis.

11. No changes were found in psoriasis, pityriasis rosea, epilepsy, meningococcic meningitis, diabetes and functional neurosis. 
12. The urea content of body fluids, in the majority of cases, agrees with the blood urea.

13. The blood pressure was taken in 178 cases. Reference to the results, as given in Table 24 , will readily show that there is no relation between blood pressure and the amount of blood urea.

14. The results of phthalein excretion in ninety-six cases agree with the observation of others, who find in most cases the percentage of phthalein excreted is diminished along with increase in blood urea (Table 23). 